\title{
The deforestation of Easter Island
}

\section{Valentí Rull}

Laboratory of Palaeoecology, Institute of Earth Sciences Jaume Almera (ICTJA-CSIC), C. Lluís Solé i Sabarís s/n, 08028 Barcelona, Spain

\section{ABSTRACT}

Easter Island deforestation has traditionally been viewed as an abrupt island-wide event caused by the prehistoric Rapanui civilization, which precipitated its own cultural collapse. This view emerges from early palaeoecological analyses of lake sediments, which showed a sudden and total replacement of palm pollen by grass pollen shortly after Polynesian settlement (800-1200 $\mathrm{CE}$ ). However, further palaeoecological research has challenged this view, showing that the apparent abruptness and island-wide synchronicity of forest removal was an artefact due to the occurrence of a sedimentary gap of several millennia that prevented a detailed record of the replacement of palm-dominated forests by grass meadows. During the last decade, several continuous (gap-free) and chronologically coherent sediment cores encompassing the last millennia have been retrieved and analysed, providing a new picture of forest removal on Easter Island. According to these analyses, deforestation was not abrupt but gradual and occurred at different times and rates, depending on the site. Regarding the causes, humans were not the only factors responsible for forest clearing, as climatic droughts as well as climate-human-landscape feedbacks and synergies also played a role. In summary, the deforestation of Easter Island was a complex process that was spatially and temporally heterogeneous and took place under the actions and interactions of both natural and anthropogenic drivers. In addition, archaeological evidence shows that the Rapanui civilization was resilient to deforestation and remained healthy until European contact, which contradicts the occurrence of a cultural collapse. Further research 
should aim to obtain new continuous cores and make use of recently developed biomarker analyses to advance towards a holistic view of the patterns, causes and consequences of Easter Island deforestation.

Key words: Rapa Nui, forest clearing, cultural collapse, last millennium, climate change, drought, fire, human disturbance, agriculture, pollen analysis.

\section{CONTENTS}

I. Introduction

II. Human settlement and main cultural developments

III. From ancient forests to present-day vegetation

(1) The ancient forests

(2) Prehistoric agriculture

(3) Modern vegetation

IV. Spatiotemporal deforestation patterns

(1) Rano Raraku

(2) Rano Aroi

(3) Rano Kao

(4) Overview

V. Natural and anthropogenic deforestation drivers

(1) Climate change on Easter Island during the last millennia

(2) Climate-human-landscape interactions

(a) Pre-settlement phase

(b) The last millennium

VI. Further research 
VII. Conclusions

VIII. Acknowledgments

IX. References

\section{INTRODUCTION}

Deforestation is a common feature linked to human settlement of forested areas. Oceanic islands are particularly sensitive to deforestation because of the low likelihood of forest regeneration resulting from the physical isolation that prevents recolonization from other potential forest sources. Therefore, deforestation of oceanic islands is often irreversible. The case of Easter Island (Rapa Nui), the easternmost Polynesian island and one of the most remote inhabited places on Earth (Fig. 1), has become iconic, as it has been considered an example of a cultural collapse purportedly caused by human overexploitation of natural resources, including the total removal of palm forests that dominated the island before human settlement. This cultural collapse of the ancient Rapanui civilization has been called ecocidal and has been used as a microcosmic model of the whole planet under current exploitation practices (Bahn \& Flenley, 1992; Flenley \& Bahn, 2003; Diamond, 2005). Other researchers have proposed that the deforestation was caused by extensive palm fruit consumption by Pacific rats (Rattus exulans), which would have hindered forest regeneration (Hunt, 2006, 2007). These rats were carried to the island by the first Polynesian colonizers, whose arrival occurred between approximately 800 CE and 1200 CE, according to different authors (Flenley \& Bahn, 2003; Hunt \& Lipo, 2006; Vargas, Cristino \& Izaurieta, 2006; Wilmshurst et al., 2011; Mieth \& Bork, 2015). According to this view, deforestation did not cause a cultural collapse, and the ancient Rapanui culture remained healthy until the arrival of the first Europeans (1722 CE), when the degradation of the Rapanui culture began, with the culture finally collapsing due to slave trading and the introduction of alien epidemic diseases (Rainbird, 2002; Peiser, 2005). Regardless of the cause, the island was completely deforested when the first Europeans arrived in 1722 CE (Zizka, 1991). 
This date (1722 CE) is usually considered the boundary between prehistoric and historic times on Easter Island.

Different timings and rates of deforestation on Easter Island have been proposed. The first estimations assumed that forest clearing took place over 600 years, between $800 \mathrm{CE}$ and 1400 CE (Flenley \& Bahn, 2003). As the surface area of the island is $164 \mathrm{~km}^{2}$, deforestation rates would have been approximately $0.27 \mathrm{~km}^{2}$ per year $\left(\mathrm{km}^{2} / \mathrm{y}\right)$. Others proposed that deforestation occurred over 370 years (1280 CE to $1650 \mathrm{CE}$ ) (Mann et al., 2008), which results in an estimated rate of $0.44 \mathrm{~km}^{2} / \mathrm{y}$. These estimations were based on palaeoecological data and pollen analyses of lake sediments. Other estimations, based on archaeological evidence, result in similar rates, as these data suggest that forest removal spanned approximately 400 years (1200 CE to $1600 \mathrm{CE}$ ) (Hunt, 2006, 2007), yielding estimates of $0.41 \mathrm{~km}^{2} / \mathrm{y}$. If we consider that forests did not cover the whole island but approximately $80 \%$ of its surface (Mieth \& Bork, 2015), these estimates should be reduced by $20 \%$, yielding a range between 0.22 and $0.35 \mathrm{~km}^{2} / \mathrm{y}$. Although deforestation of Easter Island is commonly viewed as a relatively rapid and abrupt process, these rates are slow compared to the current worldwide estimates of forest removal of $52,000 \mathrm{~km}^{2} / \mathrm{y}$ between 2000 and 2010 (FAO, 2012). At such rates, Easter Island would have been deforested in a single day. It has also been proposed that deforestation was not a single continuous event but occurred in two phases. According to this hypothesis, the first phase, between about $800 \mathrm{CE}$ and 1250-1350 CE, was dominated by woodland gardening and small-scale cutting of trees, with low-intensity forest disturbance. During the second phase, starting at 1250-1350 CE, forest clearing intensified, leading to total forest removal, which took place up to $1650 \mathrm{CE}$. This hypothesis is based on an island-wide study of dated slash-and-burn events (Mieth \& Bork, 2015) and is supported by palynological and wood macrocharcoal analyses (Orliac, 2000; Mann et al., 2008). 
Before European contact, the Rapanui people were unaware of metals. The typical megalithic anthropomorphic cult statues (moai) that characterized the ancient Rapanui culture (Fig. 2), still present and widespread across the island, were carved from soft tuff using instruments made of a harder basalt called toki (Gioncada et al., 2010; Simpson \& Dussubieux, 2018). Other instruments consisted of obsidian bladed points with cutting edges (mata'a), which were first interpreted as spear points or similar weapons; however, recent studies suggest that they were used for more peaceful labours such as cultivation, ritual scarification (Lipo, Hunt \& Horneman, 2016) and, notably, forest clearing, in combination with basalt adzes (Stevenson \& Williams, 2018). Fire was also intensively used for deforestation, as supported by palaeoecological records of charcoal increases associated with palm removal (Mann et al., 2008; Butler \& Flenley, 2010; Horrocks et al., 2012a,b, 2015). Several reasons for deforestation of the island have been proposed, such as collecting firewood or wood for building dwellings and boats, opening land areas for cultivation or obtaining rolls for moai transportation, among others (Flenley \& Bahn, 2003).

The first sound evidence for the existence of former forests on the island emerged from incipient palynological studies of lake sediments. The first available record of past woody vegetation consisted of pollen analyses from sediments of unknown age obtained by Thor Heyedahl during his $1955-56$ expedition. These analyses were performed by palynologist Olof Selling but remain unpublished. The only available mention of these analyses is by Heyerdahl, citing personal communication with Selling, who reported the common presence of pollen from composite species and possibly one palm species that is now extinct (Heyerdahl \& Ferdon, 1961). Approximately 20 years later, John Flenley and his collaborators published the first systematic pollen records from sediment cores retrieved from the approximately 40,000-year-old sediments of the three permanent freshwater bodies on the island: the Aroi marsh and the lakes Kao (or Kau) and Raraku (Fig. 3). These analyses clearly demonstrated the continuous presence of palmdominated forests until the last millennia, when they were replaced by grass meadows (Flenley 
\& King, 1984; Flenley et al., 1991). These results became paradigmatic and were (and still are) used to sustain the ecocidal hypothesis of the collapse of the ancient Rapanui culture.

Further research, however, has challenged this view and has suggested new scenarios for Easter Island's prehistory. This paper reviews the developments of palaeoecological research since Flenley's pioneer studies, with an emphasis on the potential causes of forest clearing and the spatiotemporal deforestation patterns. Relevant research questions include the following: was the deforestation abrupt or gradual? Was the deforestation synchronous and island-wide, as proposed by the pioneer studies? Or, on the contrary, did the deforestation occur at different times and at different rates, depending on the site? Was the deforestation entirely anthropogenic? Did environmental change play some role in forest clearing? This review begins with a characterization of the dramatic vegetation shift from the former forests to the modern open vegetation. The spatiotemporal deforestation patterns are analysed, and finally, the potential causes of such patterns are discussed, with an emphasis on human activities and environmental change. It should be stressed that this review uses and discusses primarily palaeoecological evidence as the most straightforward evidence for environmental and ecological changes, which are the targets herein. When necessary, pertinent archaeological and historical data are also used, albeit not discussed in depth. To facilitate reading, the first section places the topic in a historical context by briefly summarizing the main cultural developments between the island's settlement and European contact, on the basis of the archaeological, anthropological and ethnological evidence collected to date.

\section{HUMAN SETTLEMENT AND MAIN CULTURAL DEVELOPMENTS}

The issue of Easter Island's settlement by humans is complex and has been thoroughly reviewed elsewhere (Rull, 2019b). The consensus is that the prehistoric Rapanui civilization that built the moai originated from Polynesian navigators, who probably arrived from the Gambier or the Marquesas Islands (Fig. 1) (Routledge, 1919; Métraux, 1940), but the time of arrival is still 
debated. Based on archaeological evidence, arrival dates range between about $400 \mathrm{CE}$ (Heyerdahl \& Ferdon, 1961) and about 1300 CE (Wilsmhurst et al., 2011), although the most accepted range is between $800 \mathrm{CE}$ and $1200 \mathrm{CE}$ (Flenley \& Bahn, 2003; Kirch, 2010). The finding of remains of sweet potato (Ipomoea batatas) - an American plant considered the main food source during the period in which the prehistoric Rapanui society flourished, between 1200 CE and 1500 CE (Fischer, 2005; McCall, 2009) - opened the possibility of an Amerindian influence long before European contact. The presence of Amerindians (or Native Americans) on Easter Island before European contact, even before Europe-America contact, has been supported by dietary, DNA and craniometric analyses of modern and ancient Rapanui and associated flora and fauna (e.g. Storey et al., 2007; Moreno-Mayar et al., 2014; Tromp \& Dudgeon, 2015; Thorsby, 2016). However, with the available evidence, it is not possible to know whether these Americans arrived at Easter Island by themselves or were carried by Polynesians in eventual back-and-forth voyages to South America (Rull, 2019b).

Archaeological and ethnological evidence indicates that during the first few centuries of Easter Island's settlement, the entire Rapanui society was organized around the moai industry, and $>950$ moai and 300 ahus (the stone platforms where the moai were emplaced in groups) were built (Van Tilburgh (1994). The moai represented deified ancestors and were worshiped to guarantee land/sea fertility and, hence, social prosperity. This form of cult has been called the Ancient Cult or the Moai Cult (Edwards \& Edwards, 2013). During the Moai Cult, the centre of Rapanui society was the Raraku crater, which supplied the tuff from which the moai were carved, but all coastal areas were settled, and the society was organized into territorial clans (Routledge, 1919). Total population estimates during the period in which Rapanui society and the moai industry flourished (i.e. $1200 \mathrm{CE}$ to $1500 \mathrm{CE}$ ) range between about 3000 and 20,000 people, but the most common values are 6000-8000 people for the whole island (Flenley \& Bahn, 2003). At some point, which is still debated, the Moai Cult was replaced by the Birdman Cult, which involved completely different religious, political and social organization (reviewed in Robinson \& 
Stevenson, 2017). In the Birdman Cult, the symbols of fertility were the migratory birds, specifically sooty terns (Onychoprion fuscatus), that used to nest on the island's surrounding islets. The perennial and dynasty-based hierarchy of the Moai Cult disappeared, and the highest authority of the island was elected each year from among the clan chiefs on the basis of an athletic competition to obtain the first egg of the sooty terns that nested on the Motu Nui islet. This islet was situated in front of the ceremonial village of Orongo, where the athletic competition started, located on the SW crest of the Kao crater (Fig. 3). In this way, Orongo became the new geographical centre of the Rapanui culture. According to archaeological evidence, Orongo was founded no earlier than 1600 CE (Robinson \& Stevenson, 2017); therefore, the replacement of the Moai Cult by the Birdman Cult would have occurred by 1600 CE or later. The end of the moai industry would have been due to the difficulty of carving the hard basalts of the Kao crater - where the carving tools (toki) were commonly obtained (Gioncada et al., 2010; Simpson \& Dussubieux, 2018) - with the ancient Rapanui technology. Only a dozen basaltic moai are known (Van Tilburgh, 1994).

Some authors relate the shift from the Moai Cult to the Birdman Cult to internal wars and social conflicts (Routledge, 1919; Métraux, 1940; Mulloy, 1979). This idea is based on Rapanui legends, the assumption that many moai were deliberately toppled, and the finding of the abovementioned obsidian blades (mata'a), which were interpreted as spear points. However, recent archaeological evidence does not support these interpretations (Lipo et al., 2016; Stevenson \& Williams, 2018). The defenders of the ecocidal view considered the hypothetical social conflicts to be the results of resource exhaustion (including deforestation) and to have caused the population decline and cultural shift that led to the collapse of the ancient Rapanui society (reviewed in Flenley \& Bahn, 2003). However, as mentioned above, the Rapanui society was resilient to deforestation and subsisted without significant population declines until European contact (Hunt \& Lipo, 2011). 


\section{FROM ANCIENT FORESTS TO PRESENT-DAY VEGETATION}

Easter Island's forests were completely removed without leaving a trace, and there is no living witness to their composition and physiognomy. Everything we know about these ancient forests has been inferred from pollen and fossil wood analyses and knowledge of the modern features of the involved taxa. The dominant palm species, however, could not be identified. Human introductions have been significant, especially after European contact; therefore, the present-day vegetation is very different from that growing on the newly deforested island. This section briefly summarizes the available knowledge of the early forest composition and the main features of the modern vegetation, with notes on the main crops of the ancient Rapanui civilization and the historical post-contact human introductions.

\section{(1) The ancient forests}

The first inferences based on pioneer pollen analyses (Flenley \& King, 1984; Flenley et al., 1991) provided a general picture of the forest composition, which has not changed over time. The abundance of palm pollen in sediments (typically 40-70\% in Raraku and Kao) strongly suggested that these forests were dominated by one palm tree species, but the lack of suitable traits in pollen within the palm family prevented identification to the genus or species level (Fig. 4A). An early detailed morphological analysis suggested that the pollen belonged to a species of the Cocosoidae subfamily, which is represented in the Pacific region by the widespread Cocos nucifera (coconut) and Jubaea chilensis (Chilean wine palm), which inhabits the Pacific Chilean coasts (Dransfield et al., 1984) (Fig. 5B). Further discoveries of palm nut endocarps that were significantly smaller than those of coconuts and trunk and root casts that were similar to those of Jubaea seemed to support the second possibility (Grau, 1998, 2001). However, this analogy was questioned based on the conspicuous environmental differences between Easter Island and the Chilean coasts, and a possible affinity with Juania australis, an endemic palm of the Juan Fernández Islands, was suggested (Hunter-Anderson, 1998). Based on endocarp morphology, a 
new monospecific genus was described for the Easter Island palm called Paschalococos disperta, which is thought to be extinct (Zizka, 1991). A further phytolith analysis again revealed morphological similarities with J. chilensis, but a detailed statistical analysis of the morphometric characters of the phytoliths suggested the possibility that more than one palm species grew on the island (Delhon \& Orliac, 2007).

Palm pollen occurred together with pollen from several shrubs, which suggested the existence of a shrubby understorey whose main components would have been Sophora (Fabaceae), Triumfetta (Tiliaceae) (Fig. 4A), Macaranga and Acalypha (Euphorbiaceae), Coprosma (Rubiaceae) and several unidentified Asteraceae (Fig. 4D), Myrtaceae and Urticaceae/Moraceae species (Flenley \& King, 1984; Flenley et al., 1991). The occurrence and abundance of these elements vary in space and time, but they seem to have been usual components of palmdominated forests. An interesting finding was charcoal fragments corresponding to $>20$ woody taxa, which were found at three archaeological sites, with ages ranging from the early 14 th to the mid-17th century (Orliac, 2000; Orliac \& Orliac, 1998). It has been questioned whether these taxa were part of the ancient forests, as suggested by the age of their charred remains: only four of these taxa (Triumfetta, Sophora, Coprosma and Paschalococos) were found in previous palynological studies. The remaining taxa, notably, Caesalpinia (Caesalpiniaceae), Thespesia (Malvaceae), Broussonetia (Moraceae), Sapindus (Sapindaceae), Psydrax (Rubiaceae), Elaeocarpus (Elaeocarpaceae), Myrsine (Myrsinaceae), Syzygium (Myrtaceae), Pittosporum (Pittosporaceae), Alphitonia (Rhamnaceae) and Premma (Verbenaceae), are absent from palynological records, suggesting that they were not part of the ancient forests. However, their absence from pollen records could also be due to low pollen production and/or dispersal capacity, rather than to their absence in former forests. This situation is commonly observed in plants pollinated by animals (zoophilous) rather than by wind (anemophilous) (Faegri \& Van der Pijl, 1979). Alternative explanations are that these taxa were planted by Polynesian colonizers or were driftwood fragments utilized as firewood (Zizka, 1991). 
In addition to forest composition, forest cover has also been discussed. Although not explicitly stated, the first palynological works seemed implicitly to assume that Easter Island was entirely forested. The first (and the only available to date) quantitative estimation of forest cover was based on the present spatial distribution of root casts and charred palm trunks. Extrapolation of the density of these features in the better-preserved sites indicated that, prior to deforestation, approximately $80 \%$ of the island would have been covered by dense forests containing almost 20 million palm trees (Mieth \& Bork, 2015, 2017) (Fig. 5A). A different view considered that the pollen signal was compatible not only with a fully (or mostly) forested island but also with other scenarios, including a mosaic vegetation pattern with forests restricted to sites with permanent freshwater such as lakes, marshes and coastal areas with high freshwater tables (Rull et al., 2010). The lack of modern analogues for these forests and the uncertain identity of the extinct palm that dominated them prevent a sound reconstruction of the Easter Island landscape prior to deforestation.

\section{(2) Prehistoric agriculture}

After Polynesian settlement (800-1200 CE), Easter Island's forests coexisted with crops (Mieth $\&$ Bork, 2005). It has also been suggested that the forest was managed to obtain palm sap for sugar and other nutritious substances, but this suggestion was based on the modern use of Jubaea chilensis in central Chile and needs empirical confirmation (Bork \& Mieth, 2003).

Archaeological evidence has shown that the ancient Rapanui did not practice extensive cultivation or widespread irrigation; crops were restricted to small (metre-scale) garden features called manavai, whose water supply was heavily dependent on rainfall (Hunt \& Lipo, 2011; Puleston et al., 2017). To minimize evaporation and erosion, the manavai were protected from wind and surficial runoff by rock walls up to $2 \mathrm{~m}$ high, and soils were covered by rocks to preserve heat, moisture and nutrients, a practice called lithic mulching (Stevenson, Wozniack \& Haoa, 1999; Wozniack, 1999; Gossen \& Stevenson, 2005). Chemical analyses of agricultural 
soils suggest that they were more nutrient-rich than non-gardened soils, likely due to mulchingreduced leaching or active release of household organic matter (Hunt \& Lipo, 2011; Ladefoged et al., 2010). The first estimations using satellite imagery identified more than 2500 manavailike cultivation structures, for a total of $16.5 \mathrm{~km}^{2}$, which represents $10 \%$ of the island's surface (Hunt \& Lipo, 2011). Later, these estimates were increased to $13 \%$ of the coastal zone and $19 \%$ of the island surface (Ladefoged, Flaws \& Stevenson, 2013). During the first 500 years of human occupation, cultivation was carried out along the coasts and $1-2 \mathrm{~km}$ inland, and the main volcanic peaks (Kao, Pike and Terevaka) were likely forested; however, after approximately $1500 \mathrm{CE}$, these forests were also replaced by manavai structures (Mieth \& Bork, 2005). Recent investigations have shown that these agricultural practices continued, with no significant decline, until European contact (Mulrooney, 2013; Mieth \& Bork, 2015,2017; Stevenson et al., 2015; Jarman et al., 2017). In addition to these main dryland cultivation practices, palaeoecological evidence for local terrace cultivation has been found on the shores of wetlands, such as lakes Kao and Raraku and the Aroi marsh, where local irrigation systems possibly existed (Horrocks et al., 2012a,b, 2015).

Microfossil (pollen, phytolith, and starch) analysis of both dryland soils and wetland sediments has allowed the identification of the main plants of Polynesian origin that were cultivated prior to European contact, including mahute or paper mulberry (Broussonetia papyrifera; Moraceae), taro (Colocasia esculenta; Araceae), ti (Cordyline fruticosa; Asparagaceae), yam (Dioscorea alata; Dioscoreaceae), kumara or sweet potato (Ipomoea batatas; Convolvulaceae), ipu kaha or bottle ground (Lagenaria siceraria; Cucurbitaceae) and maika or banana (Musa sp.; Musaceae) (Horrocks \& Wozniak, 2008; Horocks et al., 2016). The first Europeans who landed on Easter Island in 1722 documented the cultivation of bananas, sweet potatoes, yams and sugar cane (Saccharum officinarum; Poaceae). The case of sweet potato is especially interesting, as mentioned above (Section II). 


\section{(3) Modern vegetation}

According to the available pollen records, deforested lands were initially covered by extensive, species-poor Poaceae (Fig. 4B) meadows, with aquatic or semiaquatic plants - mainly Scirpus (Cyperaceae) and Polygonum (Polygonaceae) (Fig. 4C, E) - in flooded terrains (Flenley \& King, 1984; Flenley et al., 1991). Today, the situation is very different as post-contact introductions and land management have deeply changed the island's ecosystems, leading to a fully anthropogenic landscape. Detailed accounts of historical developments and landscape transformations are available elsewhere (McCall, 1981; Fischer, 2005; Hunt \& Lipo, 2011). Today, the island is largely covered by grass meadows (90\%), with very low forest (5\%) and shrubland (4\%) cover, and pioneer and urban vegetation represent $1 \%$ of the surface (Etienne, Micheea \& Díaz, 1982). Most meadows are dominated by two widely distributed grasses, Sporobolus indicus and Paspalum scrobiculatum, but the Terevaka uplands are dominated by the endemic grass Axonopus paschalis (heriki hare). Most forests are recent plantations of Eucalyptus spp. (Myrtaceae), which was introduced from Australia, and Dodonaea viscosa (Sapindaceae), carried from tropical America, as well as the native Thespesia populnea (Malvaceae). Shrublands are largely dominated by the invasive Psidium guajava (Myrtaceae), also introduced from tropical America. Wetlands are dominated by Scirpus californicus (Cyperaceae) and Polygonum acuminatum (Polygonaceae), both also occurring in tropical America.

The angiosperm flora of the island is composed of around 180 species, of which $17 \%$ are autochthonous, $79 \%$ are introduced, and the remaining $4 \%$ are of uncertain origin. Among the introduced species, almost half $(\sim 48 \%)$ are considered to be naturalized. Globally, the families with the most species are Asteraceae and Fabaceae. Only four extant species are considered endemic to the island: Axonopus paschalis (Poaceae), Danthonia paschalis (Poaceae), Sophora toromiro (Fabaceae), and probably Paspalum forsterianum (Poaceae) (Zizka, 1991). Among these, the toromiro (S. toromiro) is considered to have been extinct in its natural habitat for the 
past 50 years and is maintained only by cultivation on the island and in several botanical gardens elsewhere (Maunder et al., 2000). Given the isolation of Easter Island, the ways in which the autochthonous species reached the island are of special significance. Interestingly, none of the autochthonous angiosperms have the potential for wind dispersal, and the main dispersal mechanisms are transport by birds (75\%) and drifting through sea water (25\%) (Carlquist, 1967, 1974).

\section{SPATIOTEMPORAL DEFORESTATION PATTERNS}

On Easter Island, there are only three volcanic craters containing permanent fresh water and sediments suitable for palaeoecological studies. These ranos (local term to designate a volcanic crater containing a permanent body of freshwater) are widespread across the island and situated at different elevations, from the coastal lowlands to the inner uplands, thus covering a wide range of environmental conditions. Therefore, an integrated palaeoecological study of these three sites can provide a general island-wide picture of long-term ecological trends. This section briefly explains the available pollen records for the last millennia to disclose the timing and rates of deforestation for each rano and its surroundings in order to obtain an island-wide picture.

\section{(1) Rano Raraku}

Rano Raraku contains a relatively small and shallow lake ( 300 m diameter, $2-3 \mathrm{~m}$ depth) situated at an $80 \mathrm{~m}$ elevation in the eastern coastal lowlands (Fig. 1B). The sedimentary infill is at least $14 \mathrm{~m}$ deep, which corresponds to an age of 34 cal kyr BP (Rull, 2016b). This lake has historically been the preferred site for Easter Island's palaeoecological studies for several reasons. First, the lake is highly accessible, and coring equipment can be easily transported to the site. Second, the most chronologically coherent stratigraphic sequences have been obtained from this lake, whereas in Aroi and Kao, frequent age inversions have usually prevented the development of suitable age-depth models (Butler \& Flenley, 2010; Horrocks et al., 2012a,b, 
2015). Third, the more evident patterns of replacement of palm forests by grass meadows have been recorded in Raraku sediments. The drawback related to this site is that the sedimentary records retrieved until a decade ago have an extensive stratigraphic gap that encompasses several millennia, including the time of interest for island deforestation. This gap is considered the main reason why the first palynological records of deforestation appeared to be abrupt (Rull et al., 2013). In the first records, this gap was 7 millennia or more, extending from $>7.5$ cal kyr BP to approximately 0.5 cal kyr BP (Flenley \& King, 1984; Flenley et al., 1991; Dumont et al., 1998). Further studies reduced the gap to approximately 3500 years ( 4 cal kyr BP to $\sim 0.5$ cal kyr BP) (Mann et al., 2008; Sáez et al., 2009), but the last millennia, when the island was deforested, remained hidden. A more recent palynological analysis showed abrupt deforestation and equally rapid grass expansion between $1.86-1.63 \mathrm{cal}$ kyr BP and $0.63-0.51 \mathrm{cal}$ kyr BP, coinciding with a sudden increase in charcoal, which is a proxy for fire, and the first signs of terrace cultivation using taro, sweet potato, banana and possibly bottle gourd (Horrocks et al., 2012a). In this case, the sedimentary gap occurred just before those dates and spanned approximately 8000 years. An almost continuous and chronologically coherent Raraku sequence (RAR08) was retrieved a few years later, which encompassed the last 5 cal kyr and included only two minor centennialscale gaps (Cañellas-Boltà et al., 2013) (Fig. 6). This sequence showed that the first deforestation event took place approximately $450 \mathrm{BCE}$ and proceeded gradually until approximately $1550 \mathrm{CE}$, with two major accelerations: one at around $1200 \mathrm{CE}$ and another at around $1450 \mathrm{CE}$ (Fig. 7). Forest retraction was continuous, and no regeneration phases were observed. The grass meadows followed an inverse trend paralleled by charcoal trends. Fire incidence was low until approximately $1200 \mathrm{CE}$, when it significantly increased in parallel with the major deforestation pulse. The grass and fire trends largely coincided with the trends of Verbena litoralis (Verbenaceae) (Fig. 4G, H), which is a weed of American origin, suggesting that humans were actively involved in island deforestation. The potential significance of $V$. litoralis for the colonization timing and origin of the first settlers is discussed elsewhere (Rull, 
$2019 b$ ). This reconstruction supported the view that the previously assumed abruptness of forest clearance was an artefact caused by the large sedimentary gap in the previous sequences. Using the palm pollen percentage as a rough estimate of the forest cover, the latest Raraku record suggests that deforestation proceeded at a general rate of approximately $-4 \%$ per century (Rull et $a l ., 2015)$, which is far from instantaneous. If we consider only the last millennium, when deforestation rates significantly accelerated, the rates increase to $-9 \%$ per century.

\section{(2) Rano Aroi}

Rano Aroi is a mire approximately $150 \mathrm{~m}$ in diameter that is situated at a $430 \mathrm{~m}$ elevation in the northern Terevaka uplands. The mire infill is predominantly peat and is at least $16 \mathrm{~m}$ thick in the centre, which represents an extrapolated age of approximately 70,000 years (Rull, 2016b). The first Aroi records did not show the palm dominance observed in Raraku for about the last 40,000 years; therefore, no deforestation events were recorded. The whole record was dominated by grasses, followed by some ferns and shrubs, and it was suggested that palm forests were restricted to lowlands and Aroi was near the uppermost treeline, where palm trees were scattered among shrublands and marshes (Flenley \& King, 1984; Flenley et al., 1991). In addition, no dates before approximately $2{ }^{14} \mathrm{C}$ kyr BP were measured, which was interpreted to be a result of vertical sediment mixing due to human disturbance in the search for freshwater. As a consequence, the usefulness of the Aroi sediments in reconstructing the vegetation history of the last millennia was questioned (Flenley \& King, 1984; Flenley et al., 1991), and the site was not cored further for approximately three decades.

A recent sedimentary sequence confirmed the former interpretation of the near-treeline vegetation (although palms were more abundant than indicated in previous analyses), and a fairly consistent chronology was obtained for the last 1000 years but not for the former 11 millennia, for which age inconsistencies were frequent (Horrocks et al., 2015). Unfortunately, the temporal resolution of the last millennium (one in four samples, or one sample every 250 years) was not 
enough for a detailed reconstruction. Despite this condition, the first signs of terrace cultivation were dated to approximately $280 \mathrm{cal}$ yr BP (1670 CE). Cultivated plants included taro, paper mulberry and banana, but sweet potato was remarkably absent, likely due to elevation. Another sedimentary sequence covering approximately the last 1500-1300 cal kyr BP was obtained in a small swamp near Rano Aroi (Rano Aroi Iti). During this time, meadows were dominant and experienced a slight increase paralleled by a similarly sized forest decline. Charcoal was present throughout the core, but no evidence of cultivation was found. Pollen of the American herb Sisyrinchium (Iridaceae) was present since the beginning and occurred throughout the core, suggesting that this plant was introduced by 450-650 CE, more than one millennium before European contact (Horrocks et al., 2015). This case is similar to that of Verbena in Rano Raraku (Cañellas-Boltà et al., 2013), and the same considerations of the first Easter Island settlers and the Polynesian discovery of America are valid here.

A fully continuous and chronologically coherent sedimentary record was obtained later in Aroi (ARO08-02), encompassing the last $2.7 \mathrm{cal} \mathrm{kyr,} \mathrm{which} \mathrm{was} \mathrm{analysed} \mathrm{at} \mathrm{a} \mathrm{multidecadal} \mathrm{resolution}$ (Rull et al., 2015) (Fig. 6). The general dominance of open grass vegetation with palms and shrubs was again confirmed, but this pattern changed markedly during the last several centuries (Fig. 7). Palm forests underwent a rapid expansion (50\% of palm pollen per century) starting at about $1400 \mathrm{CE}$ and peaked slightly after $1500 \mathrm{CE}$, which coincided with a similarly sized decrease in grasslands, indicating that the site was rather forested. Deforestation began again by $1520 \mathrm{CE}$ and was complete about 80 years later, by around $1600 \mathrm{CE}$, coinciding with an abrupt increase in fire that ceased roughly a century after the site was fully deforested and covered by grassland meadows (Rull et al., 2015). Therefore, it is possible that grasslands were also intensively burnt after forest clearing. During this event, forest clearing proceeded at a rate of over $-70 \%$ of palm pollen per century, which is ten times the rate that occurred at Raraku.

\section{(3) Rano Kao}


Rano Kao contains the largest lake on the island, which is approximately $1250 \mathrm{~m}$ in diameter and is situated at $110 \mathrm{~m}$ elevation on the southwestern end of the island. The surface of this lake is a mosaic of open water and floating mats of aquatic vegetation up to $3 \mathrm{~m}$ deep, overlying a water column approximately $10 \mathrm{~m}$ deep. The sediments are at least $21 \mathrm{~m}$ deep, and their maximum measured age is approximately $34 \mathrm{cal} \mathrm{kyr} \mathrm{BP} \mathrm{(Rull,} \mathrm{2016a).} \mathrm{The} \mathrm{pioneering} \mathrm{analyses} \mathrm{by} \mathrm{Flenley}$ \& King (1984) and Flenley et al. (1991) were not conclusive due to dating inconsistencies, probably due to the sinking of floating mats and their mixing with lake sediments (Butler, Prior \& Flenley, 2004). A further core retrieved by the same team (KAO2), covering almost the entire Holocene, was successfully dated and analysed for pollen and charcoal (Butler \& Flenley, 2010). Two deforestation events associated with coeval charcoal increases were recorded in this core [one at 1900-1850 cal yr BP (50-100 CE) and another during the last $600 \mathrm{cal} \mathrm{yr} \mathrm{BP],} \mathrm{but} \mathrm{their}$ chronology was difficult to specify due to age inversions. Between these two events, a phase of forest regeneration occurred. Despite the lack of dating precision, the second deforestation event appeared to be consistent with the classic view of deforestation after Polynesian settlement, but the first event occurred between 700 and 1100 years before Polynesian arrival, which adds support to a hypothetical earlier colonization, as suggested by the presence of Verbena and Sisyrinchium pollen in the Raraku and Aroi sequences, respectively (Cañellas-Boltà et al., 2013; Horrocks et al., 2012a).

The first continuous and chronologically coherent Kao record encompassing the last millennia (KAO05-3A) was obtained from a floating mat (Gossen, 2007); however, pollen analyses similar to those used for Raraku and Aroi and useful in unravelling deforestation patterns are still unavailable. More recently, pollen and other microfossil (phytoliths and starch) and physical [Fourier-transformed infrared (FTIR)] microscopic analyses revealed the occurrence of major deforestation events and provided evidence of terrace cultivation, but age inconsistencies prevented the development of a reliable age-depth model (Horrocks et al., 2012b). Recently, another core (KAO08-03) was retrieved from a floating mat and studied palynologically (Rull et 
al., 2018; Seco et al., 2019) (Fig. 6). This core extended from approximately 1000 to 300 cal yr $\mathrm{BP}$, and its analysis showed a gradual deforestation trend between approximately $1050 \mathrm{CE}$ and $1600 \mathrm{CE}$, with three main pulses at $1050 \mathrm{CE}, 1350 \mathrm{CE}$ and $1600 \mathrm{CE}$ (Fig. 7). The first two pulses were more intense, and forest regeneration trends were recorded between them. After the second pulse, forests almost disappeared but then experienced some recovery, which was interrupted by the $1600 \mathrm{CE}$ deforestation pulse, which permanently removed palm forests from Rano Kao. Overall, this deforestation trend occurred at an average rate of $-9 \%$ of palm pollen per century, which coincides with the rate observed for Raraku. Taken individually, the three Kao deforestation pulses occurred at rates of $-30 \%$ to $-50 \%$, or about half the rates recorded for the abrupt Aroi deforestation. The regeneration phases were slower ( $-5 \%$ to $-10 \%)$. The first deforestation pulse was not associated with a fire increase, the second occurred at the same time as a moderate fire event, and the third took place at the beginning of a major fire event (Fig. 7). This, together with a similar increase in Sporormiella fungal spores, an indicator of human presence (Van Geel et al., 2003), will be discussed in Section V.

\section{(4) Overview}

Deforestation patterns across the island were spatially and temporally heterogeneous and occurred at different rates at each site. Therefore, the hypothesis of a single and abrupt islandwide deforestation event, as proposed by the classic paradigm, was likely due to sedimentary artefacts, notably, the occurrence of a major gap in the first cores retrieved. Improved understanding of the spatiotemporal deforestation patterns was possible after the intensification of lake coring and palaeoecological analyses in the last decade, which resulted in continuous and chronologically coherent sequences of the last millennia for all sedimentary basins of Easter Island. Another interesting finding is that some forests exhibited regeneration trends between consecutive deforestation events. This occurred in Rano Kao and Rano Aroi, although in the latter case, regeneration was not preceded by a deforestation pulse. By contrast, no forest 
regeneration was observed in Rano Raraku. This suggests that deforestation pressure was continuous in some places (Raraku) and intermittent in others (Kao), adding further heterogeneity to the already irregular deforestation scenario. The differences in palm pollen curves among the three sites (Fig. 7) support the palynological signal for forest retraction and regeneration as being representative of local rather than island-wide trends (Rull et al., 2015), as suggested in pioneer palynological studies (Flenley \& King, 1984; Flenley et al., 1991). The causes of such a heterogeneous deforestation scenario in time and space should differ from those of a hypothetical single, abrupt and island-wide forest clearance event, as discussed in the next section.

\section{NATURAL AND ANTHROPOGENIC DEFORESTATION DRIVERS}

It is not unusual to attribute historical socioecological collapses to the action of single punctual causes. Sometimes the assumed causes are singular natural environmental changes that surpass the adaptation capacity of ecosystems and/or human societies (environmental determinism), whereas in other cases, the purported drivers are anthropogenic (human determinism). On Easter Island, human determinism has traditionally been the norm, as deforestation and the Rapanui cultural collapse have been attributed to anthropogenic causes such as prehistoric overexploitation, introduction of exotic species, internal conflicts and wars, and post-contact genocide. Climatic changes have rarely been considered as potential causes of cultural change, but this view has changed during the last decade. In this section, we analyse the potential role of natural and anthropogenic drivers in the island's deforestation and its cultural consequences. Rather than a shift from human determinism to environmental determinism, this should be viewed as an attempt to consider all possible drivers as well as their interactions in the form of feedbacks and synergies. This methodology has been called the strong fuzzy environmenthuman-landscape feedbacks and synergies (EHLFS) approach and uses a multiple-working- 
hypotheses framework and the strong inferential method of hypothesis testing (Rull, 2018) (Fig. 8).

\section{(1) Climate change on Easter Island during the last millennia}

The lack of empirical evidence of climatic changes on Easter Island was used previously to dismiss the potential role of climate in the purported prehistoric socioecological collapse (Diamond, 2005). Some authors have speculated about the possible effect of droughts during the Little Ice Age (LIA) (McCall, 1993), the potential influence of El Niño Southern Oscillation (ENSO) variability on Easter Island (Orliac \& Orliac, 1998; Nunn, 2000; Orliac, 2000; Nunn \& Britton, 2001; Stenseth \& Voje, 2009) or the Late Holocene climatic instability on the disappearance of palm forests (Hunter-Anderson, 1998). Others have denied such a possibility, arguing that the ENSO and other climatic systems do not produce enough variability to affect Easter Island's climate significantly (MacIntyre, 2001; Genz \& Hunt, 2003; Junk \& Claussen, 2011). However, most of these proposals were based on extrapolations from modern climates, and no palaeoclimatic evidence was available to support either view. The first evidence of a changing climate was obtained by pollen analysis of sediments from Rano Raraku (RRA5) spanning 28 to 10 cal kyr BP, which includes the Last Glacial Maximum (LGM), which was the coldest worldwide event before the Holocene when the average southern Pacific temperatures were up to $6{ }^{\circ} \mathrm{C}$ cooler than at present. However, on Easter Island, the LGM estimates based on the Raraku RRA5 core were only about $2{ }^{\circ} \mathrm{C}$ cooler than at present (Azizi \& Flenley, 2008). It was inferred that if the temperatures of the coolest glacial phase were only $2{ }^{\circ} \mathrm{C}$ below the present temperatures, Holocene temperature shifts might have been negligible, and hence, temperature shifts were unlikely to have driven the ecological changes during the last millennium, such as deforestation. However, this did not dismiss the potential influence of eventual moisture changes, mainly droughts, as proposed initially (McCall, 1993). 
Further studies interpreted the Raraku millennial-scale sedimentary gap mentioned above as evidence of an extended drought that dried out the lake and could have played a role in deforestation, together with human disturbance (Mann et al., 2008; Sáez et al., 2009). However, the finding of fairly continuous sedimentation in other cores from the same lake challenged this view. In one of these cores (RAR08), two minor gaps remained that were interpreted as evidence of lake desiccation due to climatic droughts. The first gap occurred between $500 \mathrm{CE}$ and 1200 CE, during the Medieval Climate Anomaly (MCA), and the second took place between $1570 \mathrm{CE}$ and 1720 CE, during the LIA (Cañellas-Boltà et al., 2013). Sedimentation was continuous in Rano Aroi, but two phases of vegetation opening occurred well before human settlement and were not associated with fire events, suggesting the occurrence of two phases of dry climates at 300 BCE-50 CE and 600-1100 CE, with the latter coinciding with the MCA drought recorded at Raraku. The abrupt deforestation of Rano Aroi coincided with the Raraku LIA drought (Rull et al., 2015).

\section{(2) Climate-human-landscape interactions}

The available empirical evidence of climate shifts (mostly droughts), spatiotemporal deforestation patterns and trends, and human presence and activities can be integrated into a holistic, non-deterministic scenario of Easter Island deforestation and its potential causes (Fig. 9). It is hoped that further research will improve this framework, but a synthesis of the information available to date seems pertinent to provide a unified multi-hypothesis research framework for future studies. The following is a proposal in this sense, which is subdivided into two main phases: the pre-Polynesian settlement phase (before 800-1200 CE) and the last millennium.

(a) Pre-settlement phase 
This is still a very enigmatic phase, as the existing evidence is scarce and possible interpretations are varied and somewhat speculative. The first record of forest clearing in Raraku dates to 450 BCE, but the disturbance, albeit maintained, remained of low intensity until around $1200 \mathrm{CE}$. During this very long phase (almost 1700 years), meadows expanded slightly, but the landscape continued to be forested. The appearance of Verbena, the gradual fire increase and the lack of evidence of climate change on the island were interpreted by Cañellas-Boltà et al. (2013) in terms of an anthropogenic disturbance, possibly by Amerindian people. However, the possibility of Verbena reaching the island by long-distance dispersal without human mediation cannot be ruled out. In addition, gradual charcoal increases with no signs of human disturbance during the Holocene have been found on other Pacific islands (e.g. Stevenson, 2004). The next deforestation event (by $100 \mathrm{CE}$ ) was recorded at Rano Kao and was linked to a conspicuous fire increase, suggesting human disturbance of unknown origin (Butler \& Flenley, 2010). Again, no evidence of local climatic change was recorded. By those times, Rano Aroi was not forested, but the occurrence of Sisyrinchium since 450-650 CE could be used to reinforce the hypothesis of Amerindian presence (Horrocks et al., 2015). Again, natural long-distance dispersal should not be dismissed. Another argument against an early Amerindian discovery of Easter Island is the lack of archaeological evidence for the time interval prior to Polynesian settlement. It could be argued that, during this phase, human presence was sporadic and/or intermittent, and a true autochthonous culture was not established. Another possibility is that American plants were not introduced by Native Americans but by people from other Pacific islands - possibly of the Lapita culture, which was well established in the central Pacific islands by those times (Kirch, 2010)in eventual back-and-forth voyages to South America. Such an explanation has been proposed for the introduction of sweet potato to Polynesia (including Easter Island), and the cases of Verbena and Sisyrinchium could be similar. In this case, the first deforestation steps could have also been caused by ephemeral Lapita settlements. The available evidence is not enough unequivocally to support or reject either of these possibilities, which should be considered as 
working hypotheses for further studies. Regardless of the explanation, it seems clear that the full occupation of the island and the development of an island-wide autochthonous culture did not occur until the last millennium, when Polynesians permanently settled on the island, as demonstrated by archaeological evidence (Flenley \& Bahn, 2003; Hunt \& Lipo, 2006, 2011; Vargas et al., 2006; Wilmshurst et al., 2011).

\section{(b) The last millennium}

After a long period ( 400-600 years) of apparent forest stability (or lack of evidence of forest disturbance), the first deforestation pulse during or after Polynesian settlement was detected in Rano Kao to be at about 1050 CE (Rull et al., 2018; Seco et al., 2019). The occurrence of spores of Sporormiella - a genus of coprophilous fungi living in the dung of domestic herbivores (Van Geel et al., 2003) - suggests human presence. However, the small number of these spores and the absence of fire indicate that human occupation may have been low and probably not enough to cause a deforestation event similar to that recorded. This occurred during the MCA drought that desiccated Lake Raraku, and hence, the climate may have been the main factor responsible for the $1050 \mathrm{CE}$ Kao forest clearing. The fact that Rano Aroi vegetation was apparently unaffected by this drought could be due to the maintenance of wetter conditions due to higher elevation and the occurrence of an elevational precipitation gradient, which today is almost $200 \mathrm{~mm} / 100 \mathrm{~m}$ of elevation (Puleston et al., 2017). This local deforestation event occurred during the phase of lowintensity forest disturbance proposed by Mieth \& Bork (2015), and more than a century before the dates proposed by the defenders of a late colonization, in 1200 CE or after (Hunt \& Lipo, 2006; Wilmshurst et al., 2011). According to Nunn (2007), the discovery and settlement of Easter Island occurred during the MCA (also known as the Medieval Warm Period), between $750 \mathrm{CE}$ and $1250 \mathrm{CE}$, when climatic conditions and rising sea levels would have favoured longdistance navigation among Polynesian archipelagos. 
The next deforestation episode occurred in Raraku at around $1200 \mathrm{CE}$, just after the MCA drought, under sustained, although moderate, fire pressure (Cañellas-Boltà et al., 2013). The occurrence of wetter climates more favourable for forest growth suggests that this deforestation pulse was of anthropogenic origin. Forest retreat was continuous despite fires not increasing significantly, which suggests the existence of positive feedbacks amplifying forest responses to sustained fire incidence. At the same time, the Kao forests were recovering, likely due to favourable climates and the absence of human pressure, as indicated by the lack of fires and coprophilous fungi (Rull et al., 2018; Seco et al., 2019). However, this forest regeneration was interrupted by another deforestation episode (1350 CE), likely anthropogenic, coinciding with a charcoal peak and the return of Sporormiella spores (Rull et al., 2018; Seco et al., 2019). Rano Aroi continued to be devoid of humans, and the significant forest expansion recorded between approximately $1300 \mathrm{CE}$ and $1500 \mathrm{CE}$ was likely due to the occurrence of wetter climates (Rull et al., 2015).

Rano Raraku forests disappeared after a final deforestation event by $1450 \mathrm{CE}$, coinciding with significant fire exacerbation supporting human deforestation (Cañellas-Boltà et al., 2013). At the same time, human pressure declined in Rano Kao, and its forests, which had been almost removed during the $1350 \mathrm{CE}$ deforestation pulse, experienced a new regeneration trend, although less intense than the former (Rull et al., 2018; Seco et al., 2019). At the same time, Rano Aroi was truly forested for the first time, and its forests became the most dense and extensive on the island due to the almost complete deforestation of Raraku and Kao. However, the situation changed by $1570 \mathrm{CE}$, when a sudden deforestation event completely removed these forests (Rull et al., 2015). This coincided with intense fire exacerbation, suggesting anthropogenic causes; however, the LIA drought would have acted synergistically by favouring forest flammability and preventing regeneration.

The last deforestation event on the island irreversibly removed the Kao forests by $1600 \mathrm{CE}$, coinciding with the largest human occupation of this crater, as indicated by the significant 
increase in fires and Sporormiella spores. This has been associated with the foundation of the ceremonial village of Orongo at the crest of the Kao crater, which took place at $1600 \mathrm{CE}$ (Robinson \& Stevenson, 2017), replacing the Raraku quarry as the centre of the prehistoric Rapanui culture. This geographical shift coincided with the end of the Moai Cult and the onset of a completely different social, religious and political organization known as the Birdman Cult (Rull, 2016a; Rull et al., 2018). It has been proposed that synergies between climate (drought and lake desiccation) and humans (deforestation) would have transformed Raraku into inhospitable badlands unable to support human activity and the moai industry, which was the main activity of the Rapanui civilization at the time. This would have caused massive human migration to Rano Kao, likely the only freshwater source during the LIA drought (Rull, 2019a). Taken globally, the intensification of deforestation between approximately $1200 \mathrm{CE}$ and the total disappearance of forests by around $1600 \mathrm{CE}$ coincided with the flourishing ancient Rapanui culture (Fischer, 2005; McCall, 2009) and with the phase of increased forest clearing formerly proposed by Mann et al. (2008) and Mieth \& Bork (2015), among others. However, the detailed reconstruction shown here, based on continuous sedimentary records from the three basins suitable for palaeoecological study, significantly increases the spatiotemporal resolution and provides much more detail on the patterns, processes and possible causes of the different forest removal and regeneration events.

A comment on the possibility of Pacific rats being responsible for deforestation by preventing forest regeneration seems pertinent. This was first suggested by Dransfield et al. (1984) and subsequently by Hunt $(2006,2007)$ based on findings of endocarps of the enigmatic palm species with marks of rat gnawing. Mieth \& Bork (2010) attributed this to the fact that these palm endocarps were found exposed in caves and were thus accessible to rats for long periods. These authors analysed endocarps buried in situ within charcoal layers, finding only $10 \%$ to have gnaw marks. Mieth \& Bork (2010) also found evidence for forest regeneration in a second generation of palm root casts overlying an older layer with charred wood resulting from an earlier forest 
clearing dated to 1280-1390 CE. They concluded that rats did not hinder forest regeneration and, hence, were not responsible for Easter Island's deforestation. Palynological evidence of forest regeneration found in Rano Kao and Rano Aroi, as reported herein (Butler \& Flenley, 2010; Rull et al., 2015, 2018; Seco et al., 2019), is consistent with Mieth's \& Bork’s (2010) conclusions.

\section{FURTHER RESEARCH}

Further palaeoecological efforts are still needed for a sound understanding of the timing and patterns of Easter Island deforestation and its causes. Regarding coring, only one continuous and chronologically coherent sedimentary sequence is available for the last millennium at each site; more coring is required to confirm the new insights based on these sequences. The recent development of molecular analyses, especially biomarkers, may provide valuable information on climatic shifts and human activities. For example, the use of glycerol-dialkyl-glycerol-tetraethers (GDGTs) and $n$-alkanes from plant leaf waxes may provide detailed temperature and precipitation reconstructions, respectively (Eglington \& Eglington, 2008). Regarding human presence and activities, the use of specific faecal lipids such as $5 \alpha$-stanols and bile acids can reveal the presence of humans and/or ruminant livestock (Bull et al., 2002; D’Anjou et al., 2012). Molecular DNA analyses may also provide evidence of anthropogenic activities by directly recording human presence and the occurrence of plants and animals associated with human activities (cultivation, livestock, and introduction of alien species) (Rawlence et al., 2014; Parducci et al., 2017). This is especially useful to complement pollen and other microfossil analyses (fungal spores, phytoliths, and starch) and could provide crucial evidence for the identification of the unknown palm species that dominated Easter Island forests. Infrared spectral analyses (FTIR) have also been useful for microfossil identification in Easter Island sediments, but their full potential has not yet been realized. This is a growing field of research that should be applied intensively in the future. In addition to new coring campaigns and the use of novel molecular evidence, multidisciplinary collaboration is essential, not only within the different 
palaeoresearch specialities but also among different scientific disciplines such as archaeology, anthropology, ethnology and history, among others (Rull et al., 2013). A constant in Easter Island research has been the individualistic behaviour of these disciplines, which is contrary to the integrative nature of palaeosciences and the complexity of environment-landscape-human interactions (Rull, 2018). Truly multidisciplinary studies are essential for progressing towards a sound understanding of what truly happened on Easter Island before European contact.

\section{CONCLUSIONS}

(1) The deforestation of Easter Island was not abrupt, synchronous and island-wide, as proposed by pioneer palaeoecological studies. Such earlier conclusions were based on the study of incomplete palaeoecological records consisting of sedimentary sequences containing a stratigraphic gap that hid the vegetation and landscape shifts of the last millennia. Recently recovered continuous (gap-free) sedimentary sequences including the last millennia, along with edaphic evidence of slash-and-burn events, have provided a different picture of Easter Island's deforestation, showing that forest removal on Easter Island was a largely heterogeneous process in time and space.

(2) Deforestation timing and rates differed significantly across the island. In Raraku, forest clearing started at around $450 \mathrm{BCE}$ and was not completed until approximately 2000 years later. This long and gradual process was punctuated by two acceleration events that occurred at around $1200 \mathrm{CE}$ and around $1450 \mathrm{CE}$. In Aroi, forest removal was abrupt and took place in less than a century, between about 1520 and 1600 CE. In Kao, deforestation started at 50-100 CE and ended at around $1600 \mathrm{CE}$, with two main intermediate accelerations at about $1050 \mathrm{CE}$ and about $1350 \mathrm{CE}$.

(3) Phases of forest expansion and regeneration were observed in Aroi and Kao but not in Raraku, where forest removal was a continuous process. In Aroi, forests expanded between about $1400 \mathrm{CE}$ and about $1500 \mathrm{CE}$, whereas in Kao, three phases of forest recovery were 
recorded after the deforestation accelerations occurred. These observations indicate that deforestation pressure was not homogeneous across the island.

(4) Some deforestation events could be linked to droughts, others to human activities and others to feedbacks and synergies between them. Especially significant were two secular-scale droughts that occurred during the Medieval Climate Anomaly and the Little Ice Age, which significantly reduced freshwater availability and likely prompted intra-island human migrations in search of better living conditions. Frequent fires and land use in the form of small but widespread cultivation sites were the main anthropogenic activities linked to deforestation.

(5) The reviewed archaeological evidence for prehistoric agriculture suggests that total island deforestation did not cause a cultural collapse. The ancient Rapanui civilization was resilient to forest clearance, as shown by the continuity of agricultural practices in both drylands and lake terraces. Land use did not experience significant declines, and the Rapanui civilization underwent a major cultural change but remained healthy until European contact.

(6) In summary, Easter Island deforestation appears to have been a heterogeneous process in time and space under the influence of both natural and anthropogenic drivers, which did not cause a cultural collapse. The whole picture contrasts with the former ecocidal paradigm of an island-wide abrupt forest clearing caused exclusively by humans and opens a new, more complex perspective on forest removal and its causes, as well as the potential consequences for the Rapanui culture.

\section{ACKNOWLEDGMENTS}

Continuous sediment cores encompassing the last millennia retrieved in Rano Raraku (RAR08), Rano Aori (ARO08-02) and Rano Kao (KAO08-03) were obtained during the development of projects LAVOLTER (CGL2004-00683) and GEOBILA (CGL2007-60932/BTE), funded by the Spanish Ministry of Education and Science. These projects also funded pollen processing and analysis, which was developed in the Laboratory of Paleoecology of the Institute of Earth 
Sciences Jaume Almera (ICTJA), of the Higher Spanish Council for Scientific Research (CSIC).

Discussions with the team members of these projects are greatly acknowledged, especially Núria Cañellas-Boltà, Santiago Giralt, Olga Margalef, Sergi Pla-Rabes and Alberto Sáez. The views expressed herein are the sole responsibility of the author. Comments by two anonymous reviewers contributed to improving this review.

\section{REFERENCES}

AZIZI, G. \& FLENLEY, J. R. (2008). The last glacial maximum climatic conditions on Easter Island. Quaternary International 184, 166-176.

BAHN, P. \& Flenley, J. R. (1992). Easter Island, Earth Island. Tames \& Hudson, London.

Bork, H. R. \& MIETH, A. (2003). The key rolw of Jubaea palm trees in the history of Rapa Nui, a provocative interpretation. Rapa Nui Journal 17, 119-121.

Bull, I. D., Lockheart, M. J., Elhmmali, M. M., Roberts, D. J. \& Evershed, R. P. (2002). The origin of faeces by means of biomarker detection. Environment International 27, 647654.

Butler, K. R. \& FlenLey, J. R. (2010). The Rano Kau 2 pollen diagram: paleoecology revealed. Rapa Nui Journal 24, 5-10.

Butler, K., Prior, C. A. \& Flenley, J. R. (2004). Anomalous radiocarbon datesfrom Easter Island. Radiocarbon 46, 395-420.

Cañellas-Boltà, N., Rull, V., Sáez, A., Margalef, O., BaO, R., Pla-Rabes, S., BlaAuw, M., VALERO-GARCÉS, B. \& GIRALT, S. (2013). Vegetation changes and human settlement of Easter Island during the last millennia: a multiproxy study of the Lake Raraku sediments. Quaternary Science Reviews 72, 36-48.

CARLQuist, S. (1967). The biota of long-distance dispersal. V. Plant dispersal to Pacific Islands. Bulletin of the Torrey Botanical Club 44, 129-162.

CARlQuist, S. (1974). Island Biology. Columbia University Press, New York. 
D’Anjou, R.M., Bradley, R.S., BALAScio, N.L. \& Finkelstein, D.B. (2012). Climate impacts on human settlement and agricultural activities in northern Norway revealed through sediment biogeochemistry. Proceedings of the National Academy of Sciences USA 109, 20332-20337.

DELhON, C. \& ORLIAC, C. (2007). The vanished palm trees of Easter Island: new radiocarbon and phytolith data. In The Gotland Papers. Selected papers from the VII International Conference on Easter Island and the Pacific. Migration, Identity, and Cultural Heritage (eds P. Wallin and H. Martrinsson-Wallin), pp. 97-110. Gotland University Press, Sweden. Diamond, J. (2005). Collapse. How Societies Choose to Fail or Survive. Allen Lane, London. Dransfield, J., Flenley, J. R., King, S. M., Harkness, D. D. \& RAPU, S. (1984). A recently extinct palm from Easter Island. Nature 312, 750-752.

Dumont, H. J., Cocquyt, C., Fortugne, M., Arnold, M., Reyss, J.-L., Bloemendal, J., Oldfield, F., Steenbergen C. L. M., Korthals, H. J. \& Zeeb, B. A. (1998). The end of moai quarrying and its effect on Lake Rano Raraku, Easter Island. Journal of Paleolimnology 20, 409-422.

EDWARDS, E. \& EDWARDS, A. (2013). When the universe was an island. Exploring the culrutal and spiritual cosmos of the ancient Rapanui. Hangaroa Press, Hangaroa.

Eglington, T. I. \& EgLington, G. (2008). Molecular proxies for paleoclimatology. Earth and Planetary Science Letters 275, 1-16.

Etienne, M., Michea, G. \& DíAZ, E. (1982). Flora, Vegetación y Potencial Pastoral de la Isla de Pascua. Facultad de Ciencias Agrarias, Veterinarias y Forestales, Universidad de Chile, Santiago de Chile.

FAEgri, K. \& VAN DER PIJL, L. (1979). The Principles of Pollination Ecology. Pergamon Press, Oxford.

FAO (2012). State of the World's Forests 2012. Food and Agriculture Organization of the United Nations, Rome. 
FISCHER, S.R. (2005). Island at the End of the World. The Turbulent History of Easter Island. Reaktion Books, London.

Flenley, J. R. \& BAHN, P. G. (2003). The Enigmas of Easter Island. Oxford University Press, Oxford.

FLENLEY, J. R. \& KING, S. (1984). Late Quaternary pollen records from Easter Island. Nature 307, 47-50.

Flenley, J. R., King, A. S. M, JaCKson, J. \& Chew, C. (1991). The Late Quaternary vegetational and climatic history of Easter Island. Journal of Quaternary Science 6, 85-115.

GENZ, J. \& HuNT, T. L. (2003). El Niño/southern oscillations and Rapa Nui prehistory. Rapa Nui Journal 17, 7-14.

Gioncada, A., GonZÁlez-Ferran, O., LezZerini, M., MaZzuoli, R., Bisson, M., \& RAPU, S. A. (2010). The volcanic rocks of Easter Island (Chile) and their use for the moai sculptures. European Journal of Mineralogy 22, 855-867.

GossEN, C. (2007). Report: the mystery lies in the Scirpus. Rapa Nui Journal 21, 105-110.

Gossen, C. \& Stevenson, C. M. (2005). Prehistoric solar innovation and water management on Rapa Nui. Proceedings of the Solar World Congress 4, 2580-2588.

GRAU, J. (1998). The Jubaea palm, key in the transportation of Moai on Easter Island. In Easter Island in Pacific Context. Proceedings of the Fourth International Conference on Easter Island and East Polynesia (eds C. M. STEVEnson, G. LEE and F. J. MoRIN), pp. 120-124. Easter Island Found., Los Osos.

GRAU, J. (2001). More about Jubaea chilensis on Easter Island. In Pacific 2000. Proceedings of the Fifth International Conference on Easter Island and the Pacific (eds C. M. STEVEnson, G. LEE and F. J. MORIN), PP. 87-90. Easter Island Foundation, Los Osos.

HEYERDAHL, T. \& FERDON, E. (1961). Reports of the Norwegian Archaeological Expedition to Easter Island and the East Pacific. Allen \& Unwin, London. 
Horrocks, M., Baisden, W. T., Flenley, J., FeEK, D., GonZÁlez-Nualart, L., HaOA-

CARdinali, S. \& Edmunds Gorman, T. (2012a). Fossil plant remains at Rano Raraku, Easter Island's statue quarry: evidence for past elevated lake level and ancient Polynesian agriculture. Journal of Paleolimnology 46, 767-783.

Horrocks, M., Baisden, T., Flenley, J., FeeK, D., Love, C., HAOA-CARdinali, S., GonzÁleZ NuAlart, L., \& EDMUnds Gorman, T. (2016). Pollen, phytolith and starch analyses of dryland soils from Easter Island (Rapa Nui) show widespread vegetation clearance and Polynesian-introduced crops. Palynology 41, 339-350.

Horrocks, M., Baisden, W. T., Harper, M. A., Marra, M., Flenley, J., FeeK, D., HaOACardinali, S., Keller, E. D., González Nualart, L. \& Edmunds Gorman, T. (2015). A plant microfossil record of late quaternary environments and human activity from Rano Aroi and surroundings, Easter Island. Journal of Paleolimnology 54, 279-303.

Horrocks, M., Baisden, W. T., Nieuwoudt, M. K., Flenley, J., FeeK, D., GonZÁlez Nualart, L., HaOA-Cardinali, S. \& Edmunds Gorman, T. (2012b). Microfossils of Polynesian cultigens in lake sediment cores from Rao Kau, Easter Island. Journal of Paleolimnology 47, 185-204.

HORROCKS, M. \& WOZNIAK, J.A. (2008). Plant microfossil analysis reveals disturbed forest and a mixed-crop, dryland production system at Te Niu, Easter Island. Journal of Archaeological Science 35, 126-142.

HunT, T. L. (2006). Rethinking the fall of Easter Island. New evidence points to and alternative explanation for a civilization's collapse. American Scientist 94, 412-419.

HuNT, T. L. (2007). Rethinking Easter Island's ecological catastrophe. Journal of Archaeological Science 34, 485-502.

HunT, T. L. \& LIPO, C.P. (2006). Late colonization of Easter Island. Science 311, 1603-1606.

HunT, T. L. \& LIPO, C. (2011). The Statues that Walked. Free Press, NewYork. 
HunTER-ANDERSON, R. L. (1998). Human vs. climatic impacts at Rapa Nui. Did people really cut down all those trees? In Easter Island in Pacific Context. Proceedings of the Fourth International Conference on Easter Island and East Polynesia (eds C. M. STEVEnSON, G. LEE and F. J. MORIN), pp. 95-99. Easter Island Found., Los Osos.

Jarman, C. L., Larsen, T., Hunt, T., LiPo, C., Solsvik, R., WALlsgrove, N., KA’APU-Lyons, C., Close, H. G. \& PopP, B.N. (2017). Diet of the prehistoric population of Rapa Nui (Easter Island, Chile) shows environmental adaptation and resilience. American Journal of Physical Anthropology 164, 343-361.

JunK, C. \& ClAuSSEN, M. (2011). Simulated climate variability in the region of Rapa Nui during the last millennium. Climate of the Past 7, 579-586.

KIRCH, P.V. (2010). Peopling of the Pacific: a holistic anthropological perspective. Annual Reviews of Anthropology 39, 131-148.

Ladefoged, T. N., Flaws, A. \& Stevenson, C.M. (2013). The distribution of rock gardens on Rapa Nui (Easter Island) as determined from satellite imagery. Journal of Archaeological Science 40, 1203-1212.

Ladefoged, T. N., Stevenson, C. M., HaOA, S., Mulrooney, M., Puleston, C., Vitousek, P. M. \& Chadwick, O. A. (2010). Soil nutrient analysis of Rapa Nui gardening. Archaeology in Oceania 45, 80-85.

LiPO, C. P., HunT, T. L. \& HoRnEMAN, R. (2016). Weapons of war? Rapa Nui mata'a morphometric analyses. Antiquity 90, 172.187.

MACINTYRE, F. (2001). ENSO, climate variability and the Rapanui. Part II, oceanography and the Rapanui. Rapa Nui Journal 15, 83-94.

Mann, D., Edwards, J., Chase, J., Beck, W., Reanier, R., Mass, M., Finney, B., \& Loret, J. (2008). Drought, vegetation change, and human history on Rapa Nui (Isla de Pascua, Easter Island). Quaternary Research 69, 16-28. 
Maunder, M., Culham, A., Alden, B., Zizka, G., Orliac, C., Lobin,W., Bordeu, A., RAmíRez, J. M. \& Glissmann-Gough, S. (2000). Conservation of the Toromiro tree, case study in the management of a plant extinct in the wild. Conservation Biology 14, 13411350.

McCALL, G. (1981). Rapanui. Tradition and Survival on Easter Island. University Press Hawaii, Honolulu.

MCCAll, G. (1993). Little Ice Age, some speculations for Rapanui. Rapa Nui Journal 7, 65-70.

MCCALL, G. (2009). Easter Island. In Encyclopedia of Islands (eds R. G. GILLESPIE and D. A. Clague), pp. 244-251. University of California Press, Berkeley.

MÉTRAuX, A. (1940). Ethnology of Easter Island. Bishop Museum Press, Honolulu.

MieTh, A. \& BORK, H. (2005). History, origin and extent of soil erosion on Easter Island (Rapa Nui). Catena 63, 244-260.

Mieth, A. \& BorK, H. (2010). Humans, climate or introduced rats - which is to blame for the woodland destruction on prehistoric Rapa Nui (Easter Island)? Journal of Archaeological Science 37, 417-426.

Mieth, A. \& BorK, H. (2012). Die Osterinsel - A Tour. Springer Spektrum, Berlin.

Mieth, A. \& BorK, H. (2015). Degradation of resources and successful land-use management on prehistoric Rapanui: two sides of the same coin. In Easter Island: Collapse or Transformation? A state of the Art (eds N. Cauwe ad M. De Drapper), pp. 91-112. Royal Academy of Overseas Sciences, Royal Museums of Art and History, Belgian Science Policy Office, Brussels.

MiETH, A. \& BORK, H. (2017). A vanished landscape - phenomena and eco-cultural consequences of extensive deforestation in the prehistory of Rapa Nui. In Cultural and Environmental Change on Rapanui (eds S. Haoa Cardinali, K. B. Ingersoll, D. W. Ingersoll and C. M. Stevenson), pp. 32-58. Routledge, London. 
Moreno-Mayar, J. V., Rasmussen, S., Seguin-Orlando, A., Rasmussen, M., Liang, M., Flåm, S. T., Lie, B. A., Gilfillan, G. D., Nielsssen, R., Thorsby, E., Willersev, E. \& MALASPINAS, A.-S. (2014). Genome-wide ancestry patterns in Rapanui suggest preEuropean admixture with Native Americans. Current Biology 24, 2518-2525.

MuLLOY, W. (1979). A preliminary culture-historical research model for Easter Island. In Las Islas Oceánicas de Chile (eds G. Echevarría and P. Arana), pp. 105-151. Universidad de Chile, Santiago de Chile.

Mulrooney, M. (2013). An island-wide assessment of the chronology of settlement and land use on RapaNui (Easter Island) based on radiocarbon data. Journal of Archaeological Science 40, 4377-4399.

NunN, P. D. (2000). Environmental catastrophe in the Pacific Islands around A.D. 1300. Geoarchaeology 15, 715-740.

NunN, P. D. (2007). Climate, Environment and Society in the Pacific During the Last Millennium. Elsevier, Amsterdam.

NunN, P. D. \& BRitTon, J. M. R. (2001). Human-environment relationships in the Pacific, Islands around A.D. 1300. Environmental History 7, 3-22.

ORLIAC, C. (2000). The woody vegetation of Easter Island between the early $14^{\text {th }}$ and the mid$17^{\text {th }}$ centuries AD. In Easter Island Archaeology. Research on Early Rapanui Culture (eds C. M. Stevenson and W. S. Ayres), pp. 211-220. Easter Island Foundation, Los Osos.

ORLIAC, C. \& ORLIAC, M. (1998). The disappearance of Easter Island's forest: over-exploitation or climatic catastrophe? In Easter Island in Pacific Context. Proceedings of the Fourth International Conference on Easter Island and East Polynesia (eds C. M. STEVEnson, G. LEE and F. J. MORIN), pp. 129-134. Easter Island Foundation, Los Osos.

Parducci, L., Bennet, K. D., Ficetota, G. F., Alsos, I. G., Suyama, Y., Wood, J. R. \& Pedersen, M. W. (2017). The ancient plant DNA in lake sediments. New Phytologist 214, 924-942. 
PEISER, B. (2005). From genocide to ecocide, the rape of Rapa Nui. Energy \& Environment 16, $513-539$.

Puleston, C. O., Ladefoged, T. N., HaoA, S., Chadwick, O. A., Vitousek, P. M. \& STEVENSON, C. M. (2017). Rain, sun, soil, and sweat: a consideration of population limits on Rapa Nui (Easter Island) beofre European contact. Frontires in Ecology and Evolution 5, 69, doi:103389/fevo.2017.00069.

RAINBIRD, P. (2002). A message for our future? The Rapa Nui (Easter Island) ecodisaster and Pacific environments. World Achaeology 33, 436-451.

Rawlence, N. J., Lowe, D. J., Wood, J. R., Young, J. M., Churchman, G. J., Huang, Y.-T. \& COOPER, A. (2014). Using paleoenvironmental DNA to reconstruct past environments: progresses and prospects. Journal of Quaternary Science 29, 610-626.

Robinson, T. \& Stevenson, C. M. (2017). The cult of the Birdman: religious change at 'Orongo, Rapa Nui (Easter Island). Journal of Pacific Archaeology 8, 88-102.

Routledge, K. (1919). The Mystery of Easter Island. The Story of an Expedition. Shifton, Praed \& Co., London.

RuLl, V. (2016a). Natural and anthropogenic drivers of cultural change at Easter Island: review and new insights. Quaternary Science Reviews 150, 31-41.

RULL, V. (2016b). The EIRA database: Last Glacial and Holocene radiocarbon ages from Easter Island's sedimentary records. Frontiers in Ecology and Evolution 4, 44, doi:103389/fevo.2016.00044.

RULL, V. (2018). Strong Fuzzy EHLFS: a general conceptual framework to address past records of environmental, ecological and cultural change. Quaternary 1, 10, doi:10.3390/quat1020010.

RULL, V. (2019a). Drought, freshwater availability and cultural resilience on Easter Islad (SE Pacific) during the Little Ice Age. PeerJ Preprints 7, e27681v1, doi 10.7287/peerj.preprints.27681v1. 
RuLl, V. (2019b). Human discovery and settlement of the remote Easter Island (SE Pacific).

Quaternary 2, 15, doi 103390/quat2020015.

Rull, V., Cañellas-Boltà, N., Margalef, O., SÁez, A., Pla-Rabes, S. \& Giralt, S. (2015).

Late Holocene vegetation dynamics and deforestation in Rano Aroi: Implications for Easter Island's ecological and cultural history. Quaternary Science Reviews 126, 219-226.

Rull, V., Cañellas-Boltà, N., Sáez, A., Giralt, S., Pla, S. \& Margalef, O. (2010).

Paleocology of Easter Island: evidence and uncertainties. Earth-Science Reviews 99, 50-60.

Rull, V., Cañellas-Boltà, N., Sáez, A., Margalef, O., BaO, R., Pla-Rabes, S., Valero-

GARCÉS, B. \& GIRALT, S. (2013). Challenging Easter Island's collapse: The need for interdisciplinary synergies. Frontiers in Ecology and Evolution 1, 3, doi

10.3389/fevo.2013.00003.

Rull, V., Montoya, E., Seco, I., Cañellas-Boltà, N., Giralt, S., Margalef, O., PlaRABEs, S., D’AndreA, W., BRAdLEy, R. \& SÁEZ, A. (2018). CLAFS, a holistic climaticecological anthropogenic hypothesis on Easter Island's deforestation and cultural change: proposals and testing prospects. Frontiers in Ecology and Evolution 6, 32, doi:103389/fevo.2018.00032.

Sáez, A., Valero-Garcés, B., Giralt, S., Moreno, A., Bao, R., Pueyo, J. J., Hernández, A. \& CASAS, D (2009). Glacial to Holocene climate changes in the SE Pacific. The Raraku Lake sedimentary record (Easter Island, $27^{\circ} \mathrm{S}$ ). Quaternary Science Reviews 28, 2743-2759. Seco, I., Rull, V., Montoya, E., Cañellas-Boltà, N., Giralt, S., Margalef, O., PlaRabes, S., D’Andrea, W., Bradley, R. \& SÁEZ, A. (2019). A continuous palynological record of forest clearing at Rano Kao (Easter Island, SE Pacific) during the last millennium: preliminary report. Quaternary (in press).

Simpson, D. F. \& DussubIEUX, L. (2018). A collapse narrative? Geochemistry and spatial distribution of basalt quarries and fine-grained artifacts reveal communal use of stone on Rapa Nui (Easter Island). Journal of Archaeological Science Reports 18, 370-385. 
STEnSETh, N. C. \& VoJE, K. L. (2009). Easter Island: climate change might have contributed to past cultural and societal changes. Climate Research 39, 111-114.

SteVEnson, J. (2004). A late-Holocene record of human impact from the southwest coast of New Caledonia. The Holocene 14, 888-898.

Stevenson, C. M., Puleston, C. O., Vitousek, P. M., Chadwick, O. A., HaoA, S. \& LADEFOGED, T. N. (2015). Variation in Rapa Nui (Easter Island) land use indicates producyion and population peaks prior to European contact. Proceedings of the National Academy of Sciences USA 112, 1025-1030.

Stevenson, C. M. \& WiLliams, C. (2018). The temporal occurrence and possible uses of obsidian mata'a on Rapa Nui (Easter Island, Chile). Archaeology in Oceania 53, 92-102.

Stevenson, C. M., Wozniack, J. \& HaOA, S. (1999). Prehistoric agricultural production on Easter Island (Rapa Nui), Chile. Antiquity 73, 801-812.

Storey, A. A., RAmírez, J. M., Quiroz, D., Burley, D. V., AdDison, D. J., WAlter, R., Anderson, A. J., Hunt, T., Athens, J. S., Huynen, L. \& MAtisso-Smith, E. A. (2007). Radiocarbon and DNA evidence for a pre-Columbian introduction of Polynesian chickens to Chile. Proceedings of the Nationa Academy of Sciences USA 104, 10335-10339.

ThORSBy, E. (2016). Genetic evidence for a contribution of native Americans to the early settlement of Rapa Nui (Easter Island). Frontiers in Ecology and Evolution 4, 118.

Tromp, M. \& Dudgeon, J. V. (2015). Differentiating dietary and non-dietary microfossils extracted from human dental calculus: The importance of sweet potato to ancient diet on Rapa Nui. Journal of Archaeological Science 54, 54-63.

VAn Geel, B., BuUrman, J., BrinkKemper, O., Schelvis, J., Aptroot, A., VAn ReEnen, G. \& HAKBIJL, T. (2003). Environmetal reconstruction of a Roman Period settlement site in Uitgeest (The Netherlands), with special reference to coprophilous fungi. Journal of Archaeological Science 30, 873-883. 
VAn Tilburg J. A. (1994). Easter Island: Archaeology, Ecology, and Culture. Smithsonian Institution Press, Washington.

VArgas, P., Cristino, C. \& Izaurieta, R. (2006). 1000 Años en Rapa Nui. Arqueología del Asentamiento. Editorial Universitaria, Santiago.

Wilmshurst, J. M., Hunt, T. L., LiPO, C. P. \& Anderson, A. J. (2011). High-precision radiocarbon dating shows recent and rapid initial human colonization of East Polynesia. Proceedings of the National Academy of Sciences USA 108, 1815-1820.

WOZNIACK, J. A. (1999). Prehistoric horticultural practices on Easter Island: lithic mulched gardens and field streams. Rapa Nui Journal 13, 95-99.

ZIZKA, G. (1991). Flowering Plants of Easter Island. Palmarum Hortus Francofurtensis, Frankfurt Main. 


\section{Figure legends}

Fig. 1. (A) Map of the main Pacific islands and archipelagos, showing the position of Easter Island (red dot). West-east peopling trends from continental Asia are indicated by orange arrows (Kirch, 2010). (B) Map of Easter Island indicating the wetlands (ranos) cored for palaeoecological studies (blue areas). Present-day planted forests, mainly of Eucalyptus (Myrtaceae), are indicated in green. Elevation is shown in metres.

Fig. 2. Moai complex of Ahu Tongariki, near Rano Raraku, with the Poike cliffs in the background. These moai are up to $9 \mathrm{~m}$ high and 90 tons in weight. Photograph: V. Rull.

Fig. 3. Google Earth images of the three ranos cored for palaeoecological analyses and their location on the island. The dark-green areas at the centre of the island are planted Eucalyptus forests. All cores retrieved historically from the three sites are shown (white dots); the recent continuous and chronologically coherent sequences are highlighted using red dots and blue names. Redrawn from Rull (2016).

Fig. 4. Selected representative pollen types from lake/marsh sediments in Easter Island. (A) Unknown palm species; (B) Poaceae; (C) Cyperaceae; (D) Asteraceae; (E) Polygonum; (F) Triumfetta; (G,H) Verbena litoralis. A-F are from Rano Aroi (Rull et al., 2015); G and H are from Rano Raraku (Cañellas-Boltà et al., 2013).

Fig. 5. Palm forests of Easter Island. (A) Hypothetical reconstruction of ancient palm forests in Poike (drawing by Gerd Close). (B) Palm forest of Jubaea chilensis from La Campana (Chile) (photograph: A. Mieth). Images from Mieth \& Bork (2010, 2012) courtesy of A. Mieth. 
Fig. 6. Age-depth models of the continuous and chronologically coherent sedimentary records of the last millennia obtained in Rano Raraku, Rano Aroi and Rano Kao. Reproduced from Cañellas-Boltà et al. (2013) (Raraku) and Rull et al. (2015, 2018) (Aroi and Kao), with permission.

Fig. 7. Synthetic diagrams of Rano Raraku, Rano Kao and Rano Aroi for interval between ca. 950 to 1850 CE. Droughts are depicted as grey bands. Red triangles indicate deforestation pulses, and forest regeneration trends are indicated by blue arrows. Palm and grass pollen is expressed in percentage and charcoal concentration in particles per gram (part $\mathrm{g}^{-1}$ ). Raw data and full diagrams are in Cañellas-Boltà et al. (2013) (Raraku), Rull et al. (2018), Seco et al. (2019) (Kao), and Rull et al. (2015) (Aroi).

Fig. 8. Graphical representation of the strong fuzzy environment-humans-landscape feedbacks and synergies (EHLFS) approach for Easter Island's ecological and cultural changes (Rull, 2018). E, Environment; H, humans; L, landscape. Feedbacks are represented by blue arrows, and synergies by red arrows. Grey arrows are internal feedbacks.

Fig. 9. Spatio-temporal deforestation patterns of Rano Aroi, Rano Kao and Rano Raraku areas and their potential drivers after Polynesian settlement, using the information in Fig. 7. Forest cover was estimated by palm pollen percentage. The blue arrow indicates the migration of the cultural core of the Rapanui society from Rano Raraku to Rano Kao. See text for detailed explanations. 

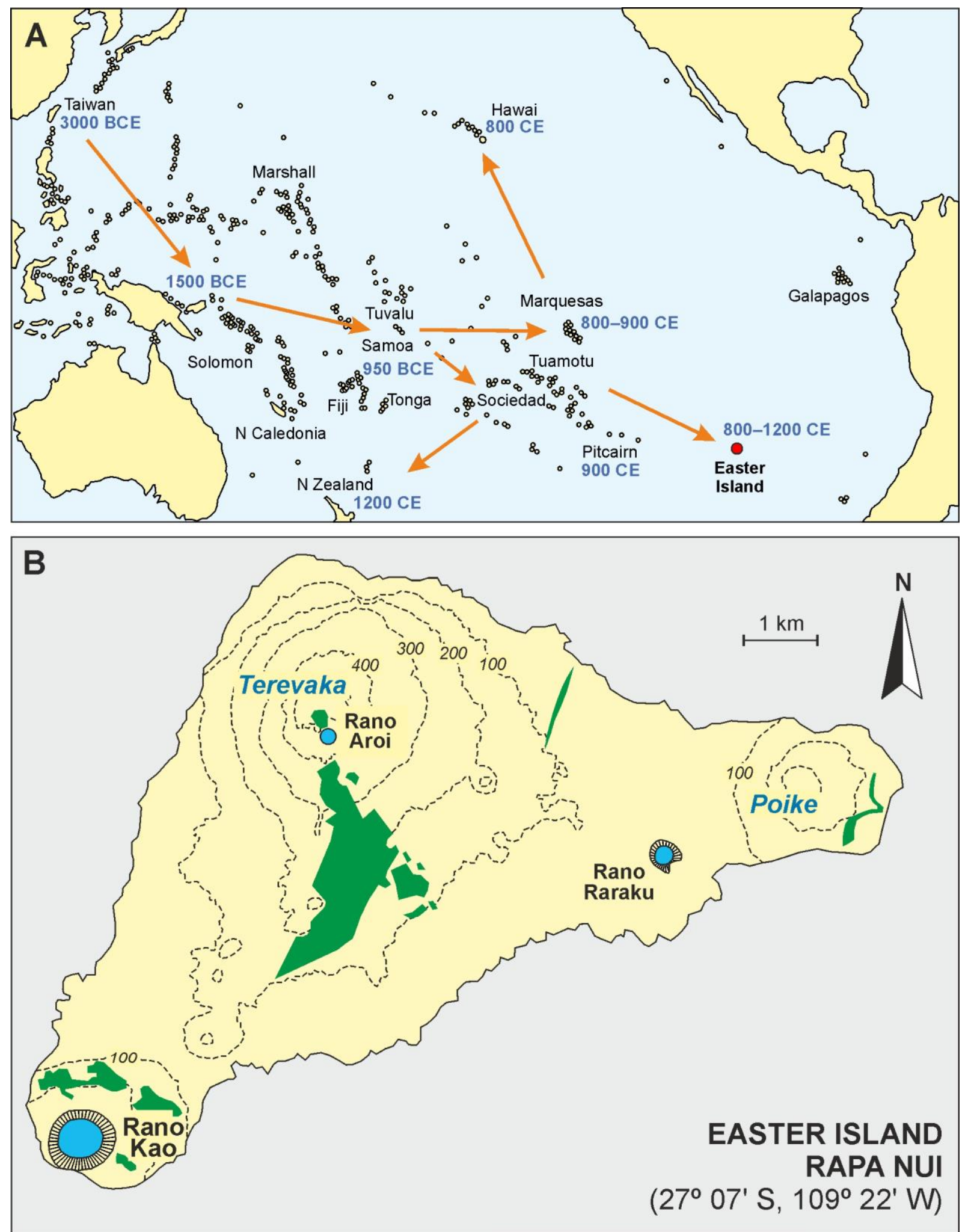

Figure 1 


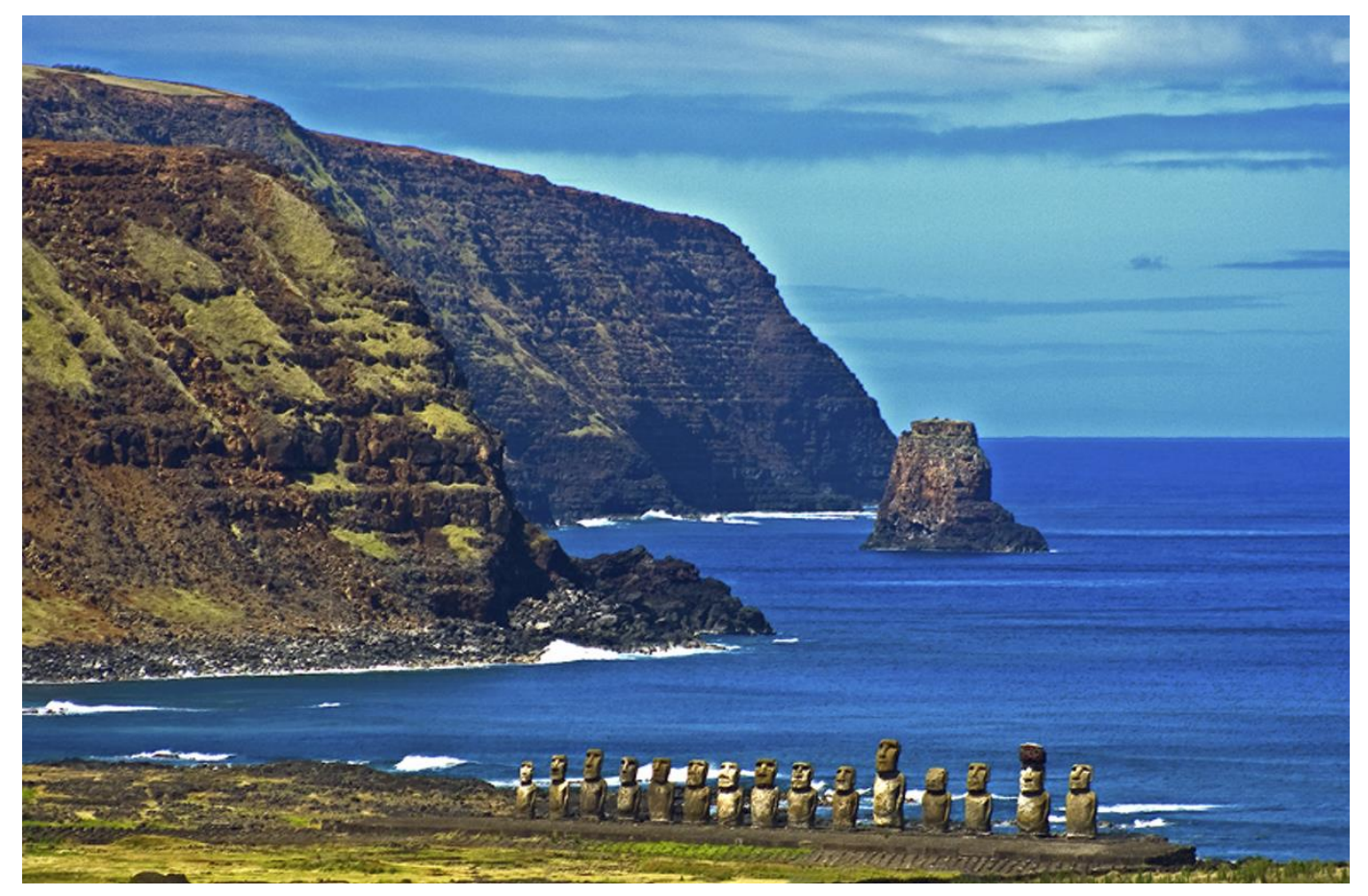

Figure 2 

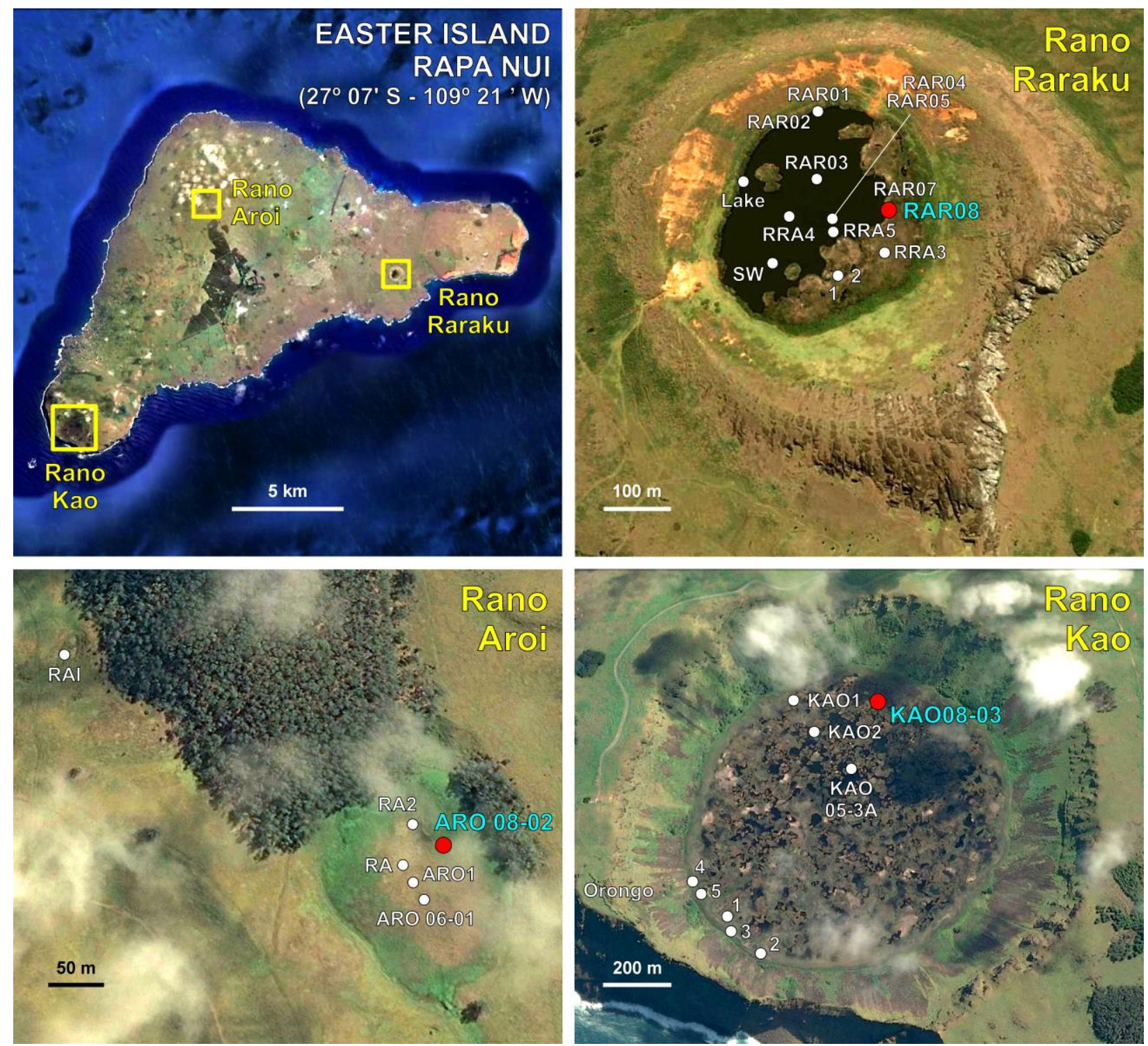

Figure 3 


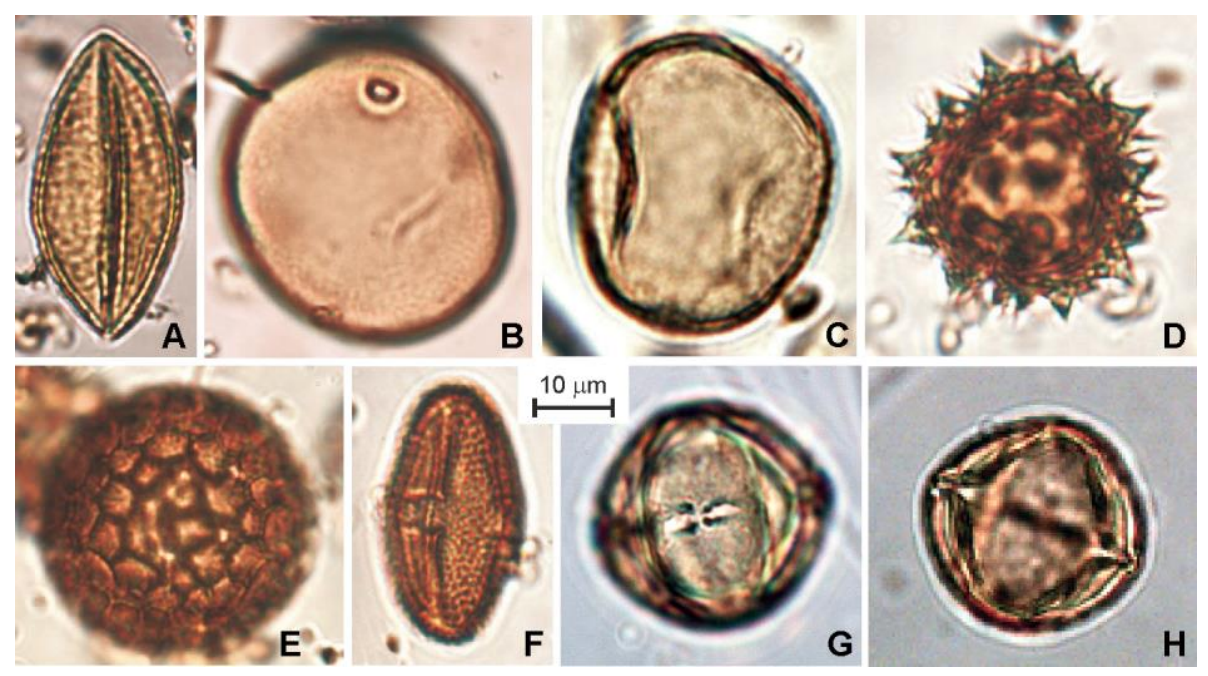

Figure 4 

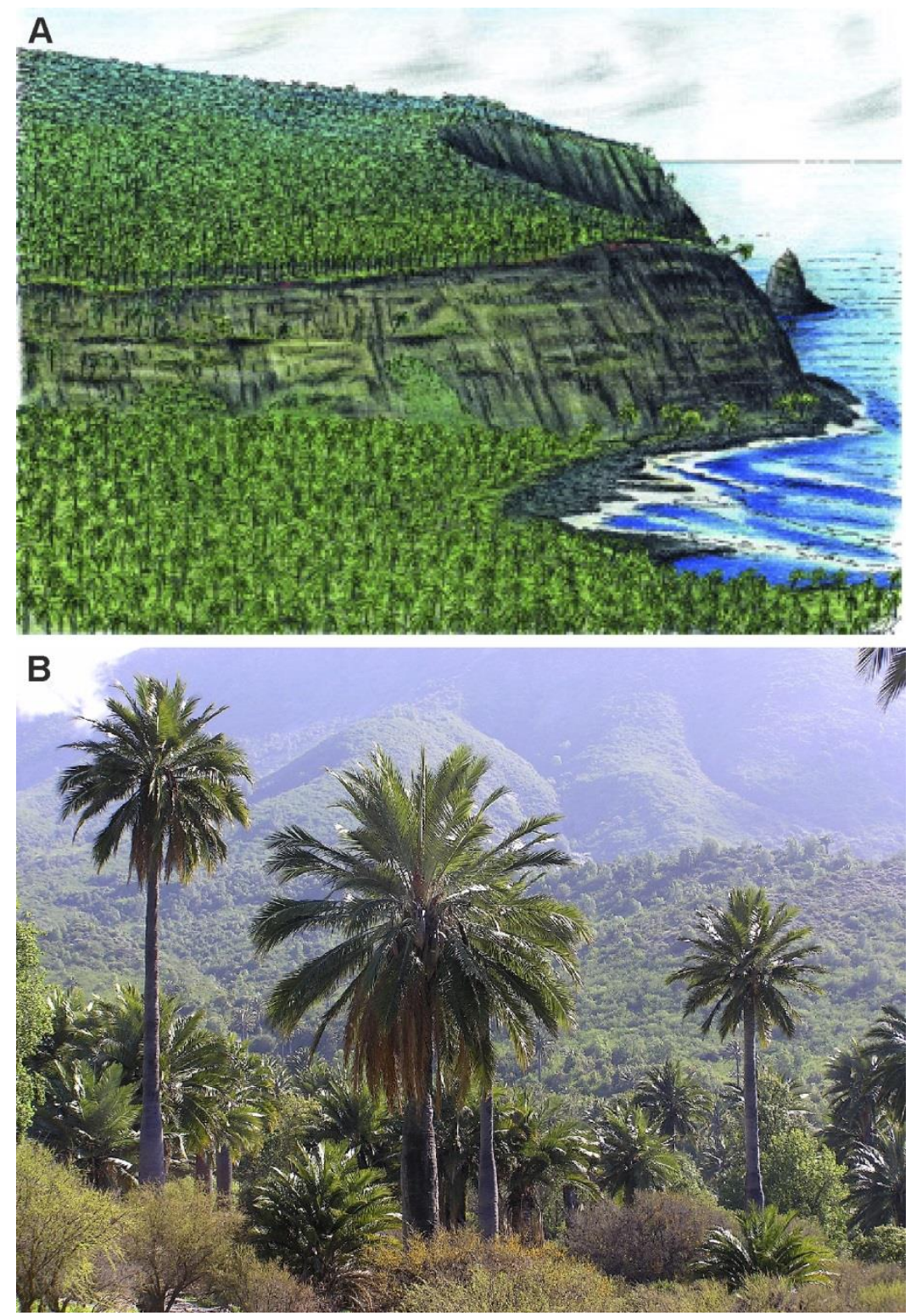

Figure 5 

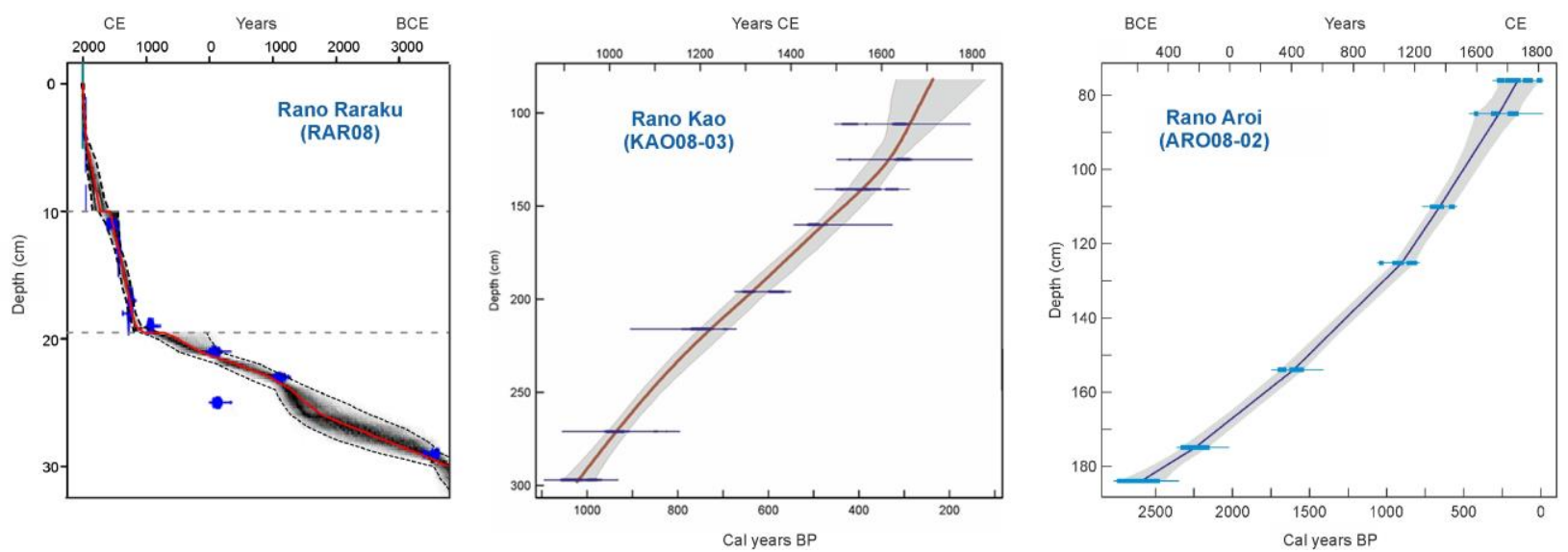

Figure 6 


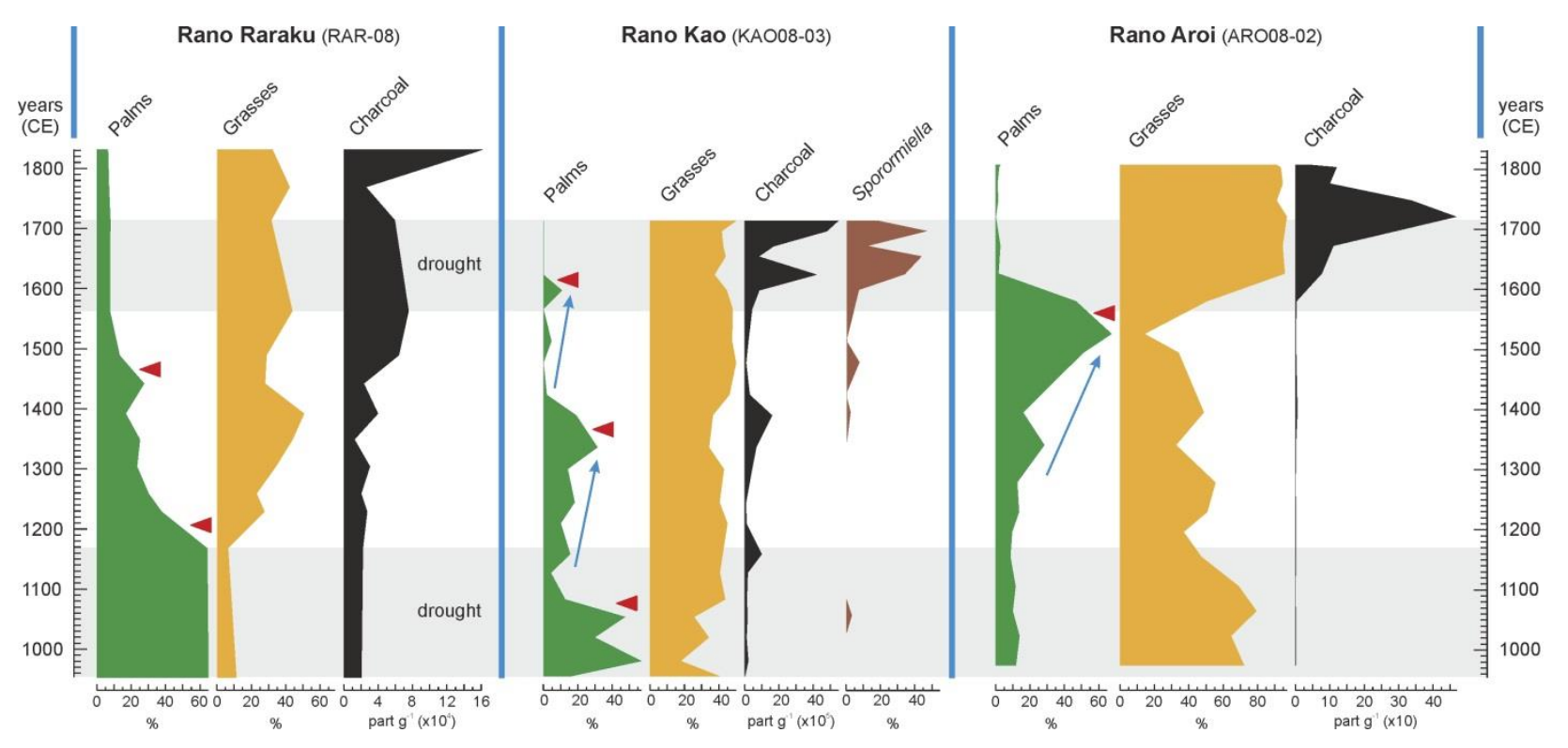

Figure 7 


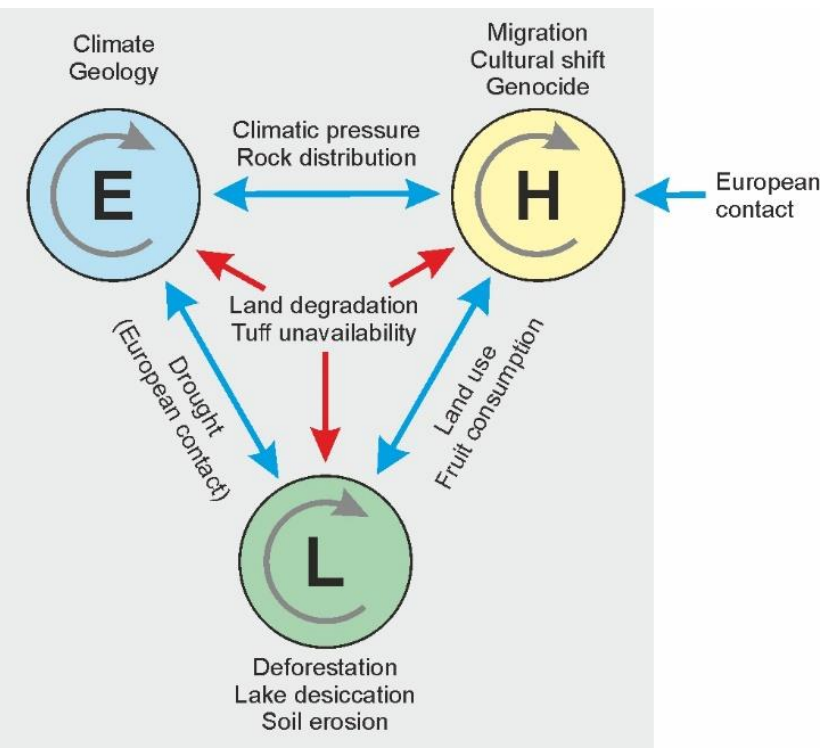

Figure 8 

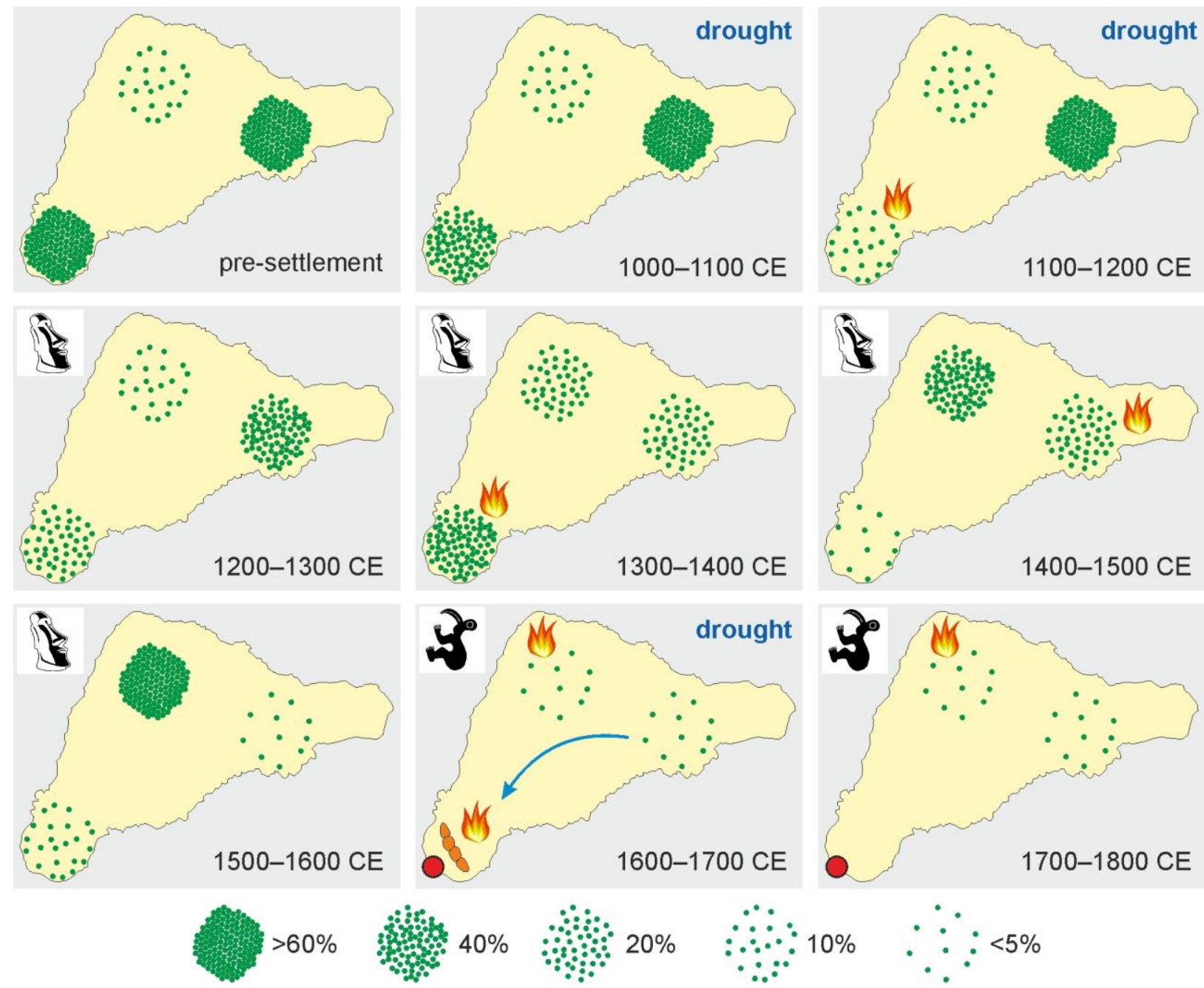

Mr fire

re coprophilous

increase fungi

$20 \%$

$\therefore \therefore 10 \%$

$\therefore \therefore<5 \%$

Figure 9 